\title{
Phylogeography unplugged: comparative surveys in the genomic era
}

\author{
${ }^{1}$ Hawai'i Institute of Marine Biology, \\ University of Hawai'i, Kaneohe, \\ Hawaii 96744. \\ ${ }^{2}$ Indian Institute of Science, \\ Bangalore, Karnataka 560012, India. \\ 3 University of Miyazaki, Faculty of \\ Agriculture, Department of Marine \\ Biology and Environmental Sciences, \\ Japan. \\ ${ }^{4}$ Marine Laboratory, University of \\ Guam, Mangilao, Guam 96923. \\ 5 Department of Botany and Zoology, \\ Stellenbosch University, Matieland, \\ 7602, South Africa. \\ ${ }^{6}$ Florida Museum of Natural History, \\ University of Florida, Gainesville, \\ Florida 32611. \\ 7 Section of Ichthyology, California \\ Academy of Sciences, San Francisco, \\ California, 94118. \\ ${ }^{8}$ Marine Science Institute, University \\ of California Santa Barbara, and \\ Brian W Bowen ${ }^{1 *}$ \\ Kartik Shanker ${ }^{2}$ \\ Nina Yasuda ${ }^{3}$ \\ Maria Celia (Machel) D Malay ${ }^{4}$ \\ Sophie von der Heyden ${ }^{5}$ \\ Gustav Paulay ${ }^{6}$ \\ Luiz A Rocha ${ }^{7}$ \\ Kimberly A Selkoe 8 \\ Paul H Barber ${ }^{9}$ \\ Suzanne T Williams ${ }^{10}$ \\ Harilaos A Lessios ${ }^{11}$ \\ Eric D Crandall ${ }^{12}$ \\ Giacomo Bernardi ${ }^{13}$ \\ Christopher P Meyer ${ }^{14}$ \\ Kent E Carpenter ${ }^{15}$ \\ Robert J Toonen ${ }^{1}$
} National Center for Ecological Analysis and Synthesis, Santa Barbara, California 93101.

${ }^{9}$ Department of Ecology and Evolutionary Biology, University of California at Los Angeles, Los Angeles, California.

${ }^{10}$ Life Sciences Department, Natural History Museum, London SW7 5BD, UK.

"Smithsonian Tropical Research Institute, Balboa, Ancon, Panama.

${ }^{12}$ Southwest Fisheries Science Center, National Marine Fisheries Service, Santa Cruz, California.

${ }^{13}$ Department of Ecology and Evolutionary Biology, University of California, Santa Cruz, California.

${ }^{14}$ Smithsonian Institution, Washington, DC 20013.

${ }^{15}$ Department of Biological Sciences, Old Dominion University, Norfolk, Virginia 23529.

* Corresponding author email: <bbowen@hawaii.edu>.

Date Submitted: 8 January, 2013. Date Accepted: 3 September, 2013. Available Online: 7 January, 2014.
ABSTRACT.-In March 2012, the authors met at the National Evolutionary Synthesis Center (NESCent) in Durham, North Carolina, USA, to discuss approaches and cooperative ventures in Indo-Pacific phylogeography. The group emerged with a series of findings: (1) Marine population structure is complex, but single locus mtDNA studies continue to provide powerful first assessment of phylogeographic patterns. (2) These patterns gain greater significance/power when resolved in a diversity of taxa. New analytical tools are emerging to address these analyses with multi-taxon approaches. (3) Genome-wide analyses are warranted if selection is indicated by surveys of standard markers. Such indicators can include discordance between genetic loci, or between genetic loci and morphology. Phylogeographic information provides a valuable context for studies of selection and adaptation. (4) Phylogeographic inferences are greatly enhanced by an understanding of the biology and ecology of study organisms. (5) Thorough, range-wide sampling of taxa is the foundation for robust phylogeographic inference. (6) Congruent geographic and taxonomic sampling by the IndoPacific community of scientists would facilitate better comparative analyses. The group concluded that at this stage of technology and software development, judicious rather than wholesale application of genomics appears to be the most robust course for marine phylogeographic studies. Therefore, our group intends to affirm the value of traditional ("unplugged") approaches, such as those based on mtDNA sequencing and microsatellites, along with essential field studies, in an era with increasing emphasis on genomic approaches. 
At the NESCent Indo-Pacific catalysis meeting in March 2012, authors met to discuss issues in comparative marine phylogeography. Our goal here is to map out a robust study design for marine phylogeography in this genomic era (see Selkoe et al. 2008, Hellberg 2009, Marko and Hart 2011, Riginos and Liggins 2013 for reviews of the latest analytical approaches). Phylogeographic studies of marine systems differ from terrestrial systems in many respects, including (1) greater diversity of major evolutionary lineages; (2) species with vast ranges, extensive dispersal potential, and large effective population sizes; (3) habitats that can be difficult, expensive, and sometimes dangerous to sample; and (4) poor understanding of factors controlling rates and pathways of gene flow. These conditions apply to all phylogeographic studies, but are nearly universal in marine systems. The corresponding uncertainties may limit phylogeographic inference in marine compared with terrestrial studies of similar scope. In this essay, our goal is to summarize lessons from the past, make recommendations for study design and resolve the path forward for marine phylogeographic surveys, in an era of ever-increasing genomic information.

\section{A Brief History}

At the inception of phylogeography, Avise et al. (1987) noted the primary roots of this field in biogeography, phylogenetics, and population genetics. All of those fields in turn have predecessors with foundations in morphology and field observations. As these fields advanced into biochemical and molecular methodologies, a few practitioners lamented the loss of what came before. Although protein gel electrophoresis opened up the possibility of determining gene flow among populations for the first time, it could not replace the knowledge gleaned from hundreds of specimens, or thousands of hours of observations. Field biologists made observations about organisms that could not be revealed by laboratory-based analyses, many which were important for meaningful interpretation of bands on a gel. Sometimes that traditional knowledge was used, sometimes ignored, and sometimes forgotten. Certainly, a little intimacy was lost in the relationship between scientist and subject, as funding priorities for research shifted.

Richard Lewontin, one of the pioneers of protein electrophoresis (Hubby and Lewontin 1966), famously wondered 25 yrs later whether this technology was a boon or bane to organismal biology (Lewontin 1991). He noted the loss of informative studies on morphology and cytogenetics, and the shift in funding priorities to laboratorybench science. A few years earlier, Wes Brown and colleagues introduced mtDNA for population and evolutionary studies (Brown and Wright 1975, Avise et al. 1979), and soon the tools shifted yet again. The mtDNA sequence information made it possible to estimate the relationships among species based on direct comparisons of nucleotide sequence data, instead of allele frequency data typical of allozyme studies. Tissue preservation requirements were also less stringent, and it became possible to incorporate historical data from museum collections. During the subsequent heyday of single marker mtDNA studies, some practitioners noted that the research lacked equal resolution in the nuclear genome. Researchers in the new field of molecular ecology knew that mtDNA was missing something that predecessors valued: the genetic contribution from both parents (Quinn and White 1987, Karl et al. 1992).

When the chain-termination method of DNA sequencing was published (Sanger and Coulson 1975), the process was impractical for most organismal laboratories 
because of the vast resources needed to determine the sequence. The chemical modification and cleavage method (Maxam and Gilbert 1977) allowed direct sequencing of purified DNA, but the process remained technically complex and impractical for population studies. With the exception of a few very well-funded laboratories, attempts to sequence DNA were not routine until computer and laboratory technology advanced to the point where by the early 1990s laboratories were able to sequence thousands of base pairs if they could manage the cost (both in terms of labor and reagents required). Polymerase chain reaction (PCR) assays were used to greatly increase the accessibility of the nuclear genome (Karl and Avise 1993). The Human Genome Project led engineers and scientists around the world to improve the speed and accuracy of sequencing reads, which led to increased availability and a concordant reduction in the overall cost associated with DNA data (Watson 1990).

With the advent of massively parallel "next generation" sequencing it is now possible to generate genomic data and assess phylogeography on scales never before considered (e.g., Puritz et al. 2012a). We can now survey entire nuclear, mitochondrial, and chloroplast genomes, and even the expression of genomes (Carstens et al. 2012). Based on the arc of events described above, is this phase the end of history as we know it for single-locus studies in phylogeography? The latest advances into next generation sequencing have opened the gateway to rapid scientific advances, but we currently are limited by the computing power and analytical methods required to take full advantage of the new data and handle the massive increase in numbers of loci and sequence length (Rocha et al. 2013, Willette et al. 2014).

\section{The Comparative Advantage}

The first lesson that stands out from two decades of comparative marine phylogeography is that large-scale patterns in genetic or species diversity are the result of multiple drivers. Even closely related and co-distributed species with similar pelagic larval duration (PLD) can exhibit radically different patterns of genetic structure (Table 1).

Much of large-scale biogeography has been built on top-down approaches, often based on 200 yrs of accumulated distribution data; for example large-scale diversity patterns have led to hypotheses that attribute such patterns to singular evolutionary processes, even though there is every reason to expect that multiple processes are in play (Paulay 1997). The center of origin (or diversification), center of accumulation, and center of overlap hypotheses are classic examples of this plurality in Indo-Pacific biogeography (Barber 2009, Bowen et al. 2013). In contrast, phylogeographic studies are bottom up, built one species at a time: once assembled from many species-level analyses, they provide a powerful framework for evaluating broad distributional patterns. If one wants to understand complex geographic patterns of biodiversity, then species or lineages are the relevant unit of replication: data from a multitude of taxa are needed. Thus far, the diversity of patterns at the species level indicates that global phylogeographic patterns are the result of the combined effects of multiple forces operating over different spatial, temporal, and ecological scales. Greater replication across species is desirable to quantify the prevalence of different processes.

While single species cannot elucidate general trends on their own, they provide the building blocks for subsequent comparative phylogeography. Sometimes single taxon studies are the only feasible logistic approach due to funding and geopolitical 


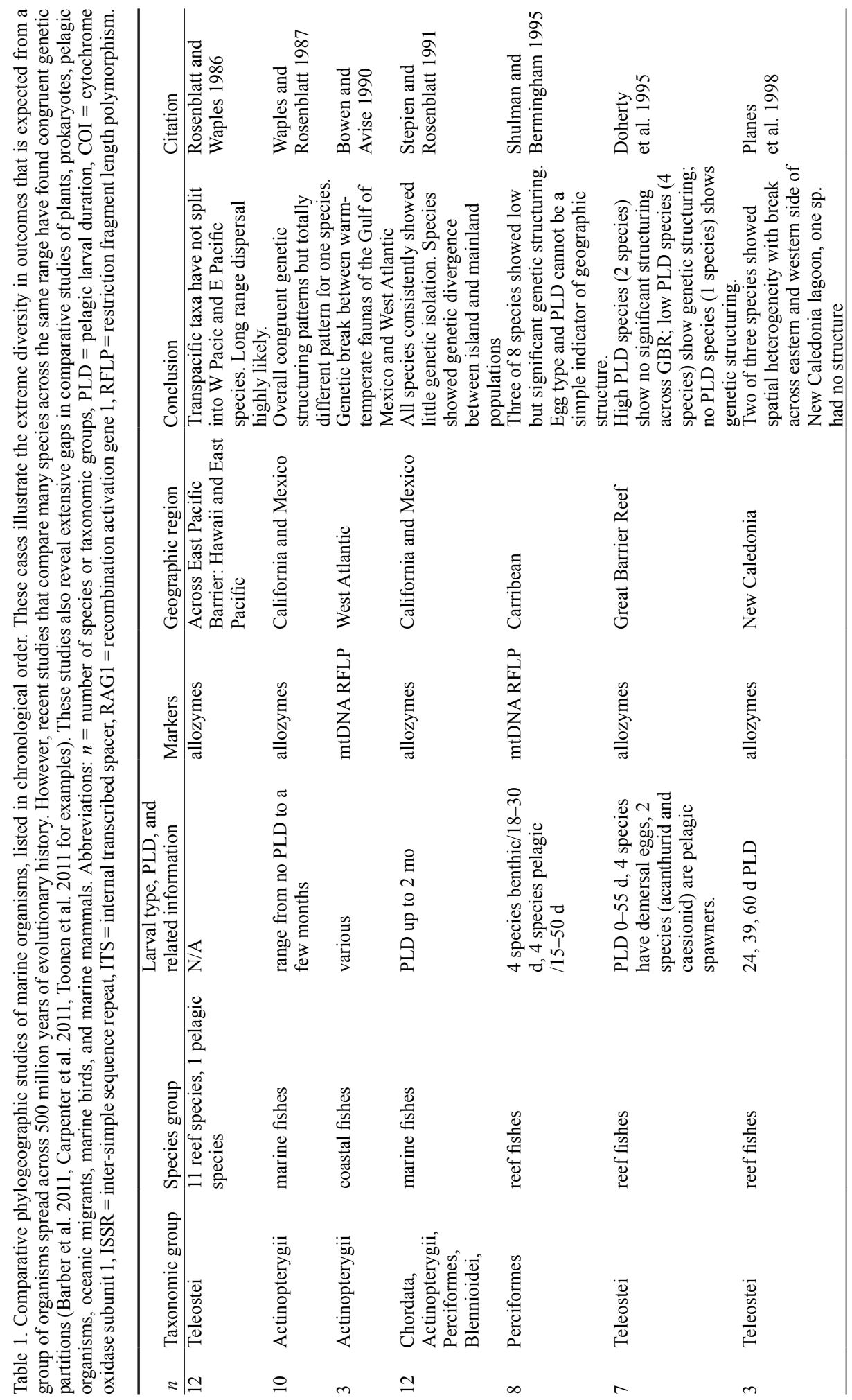




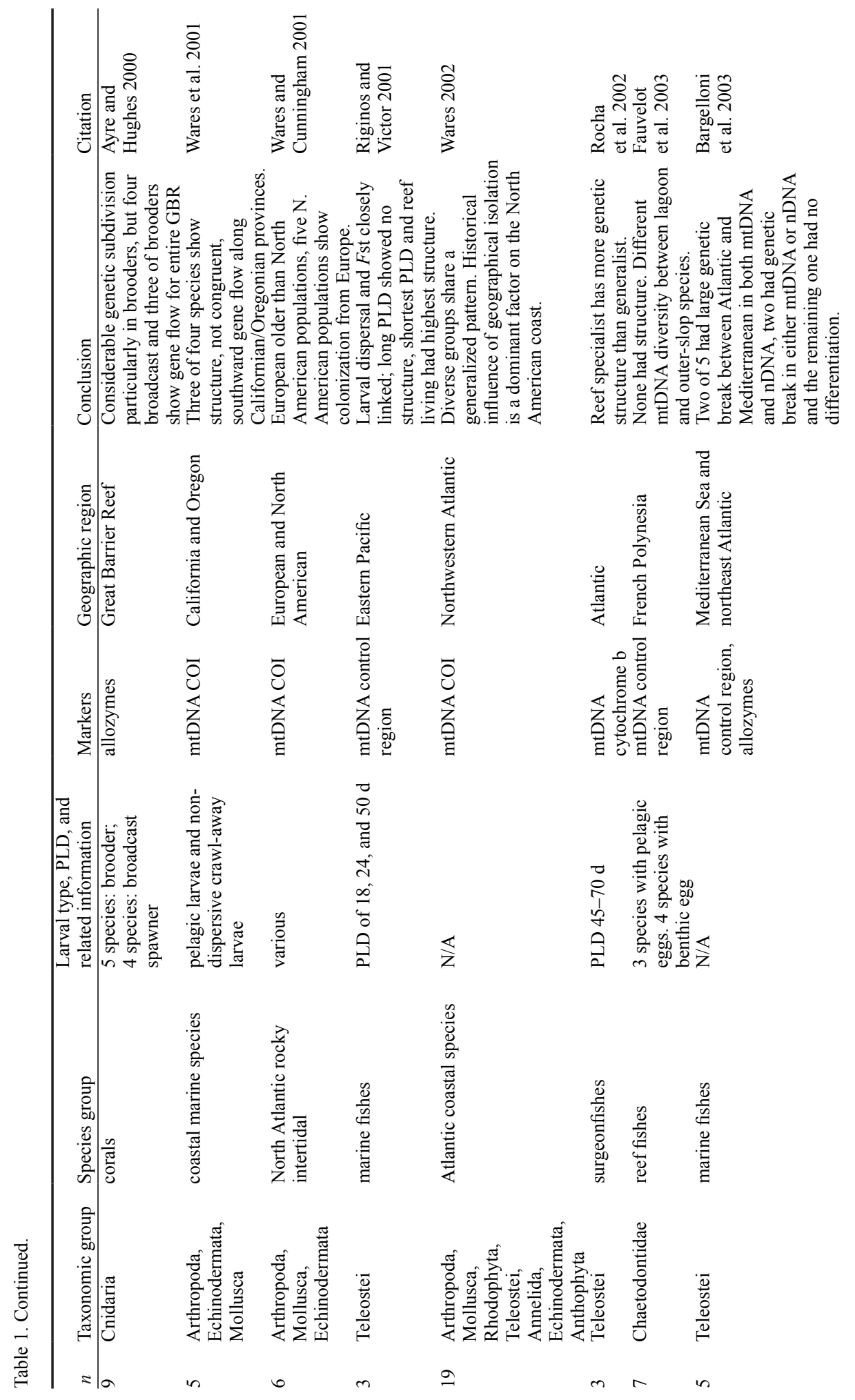




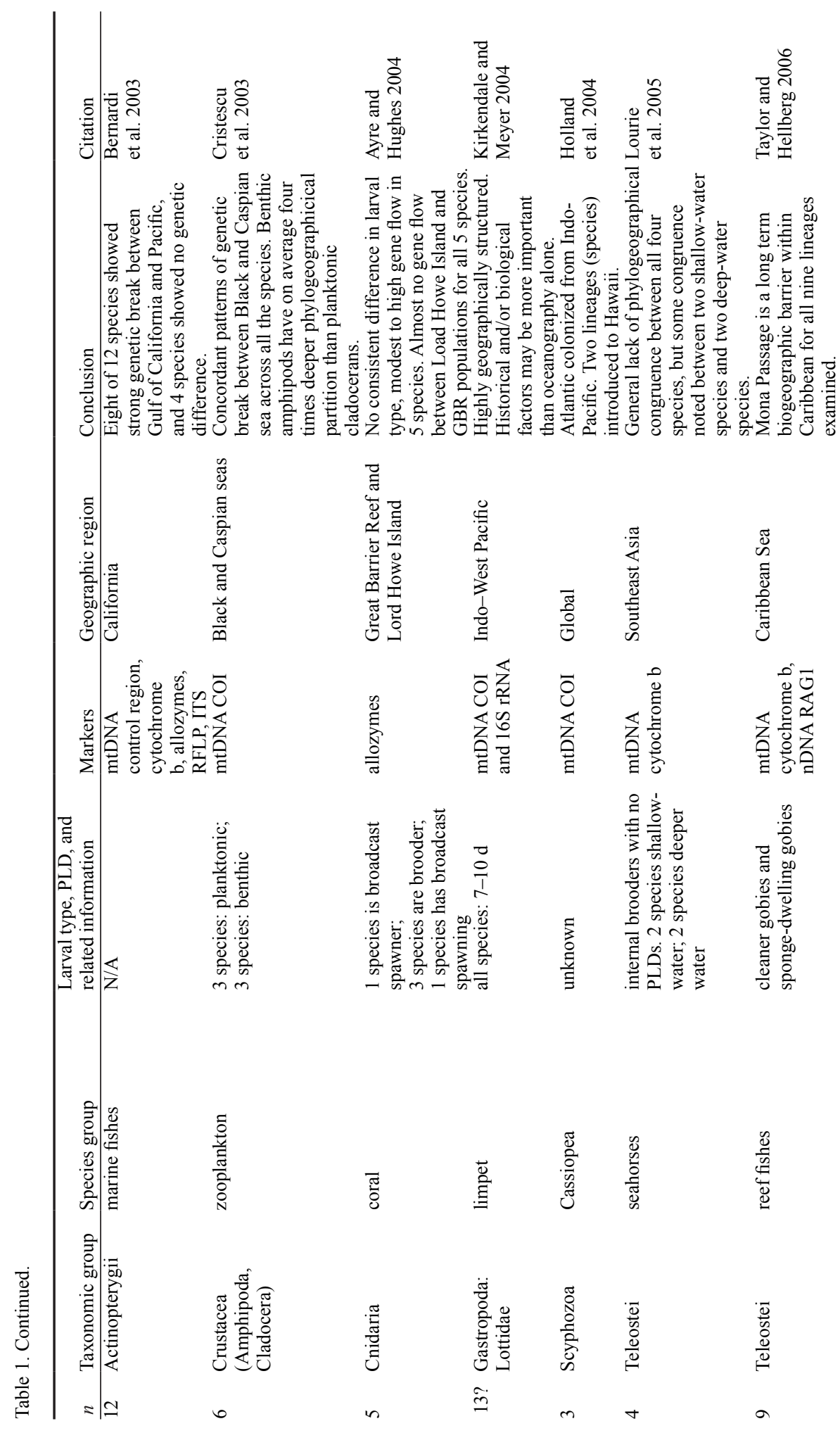




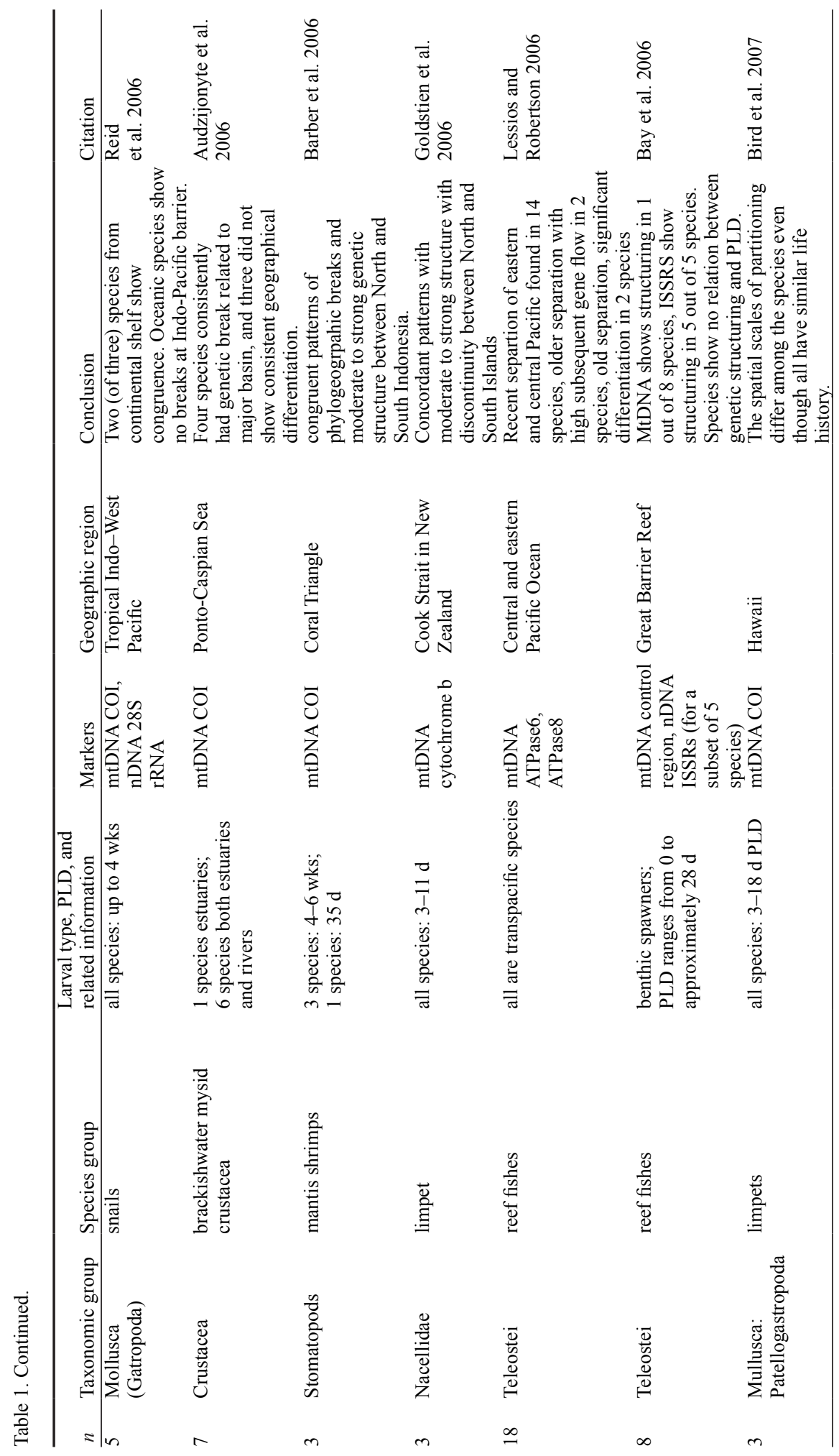




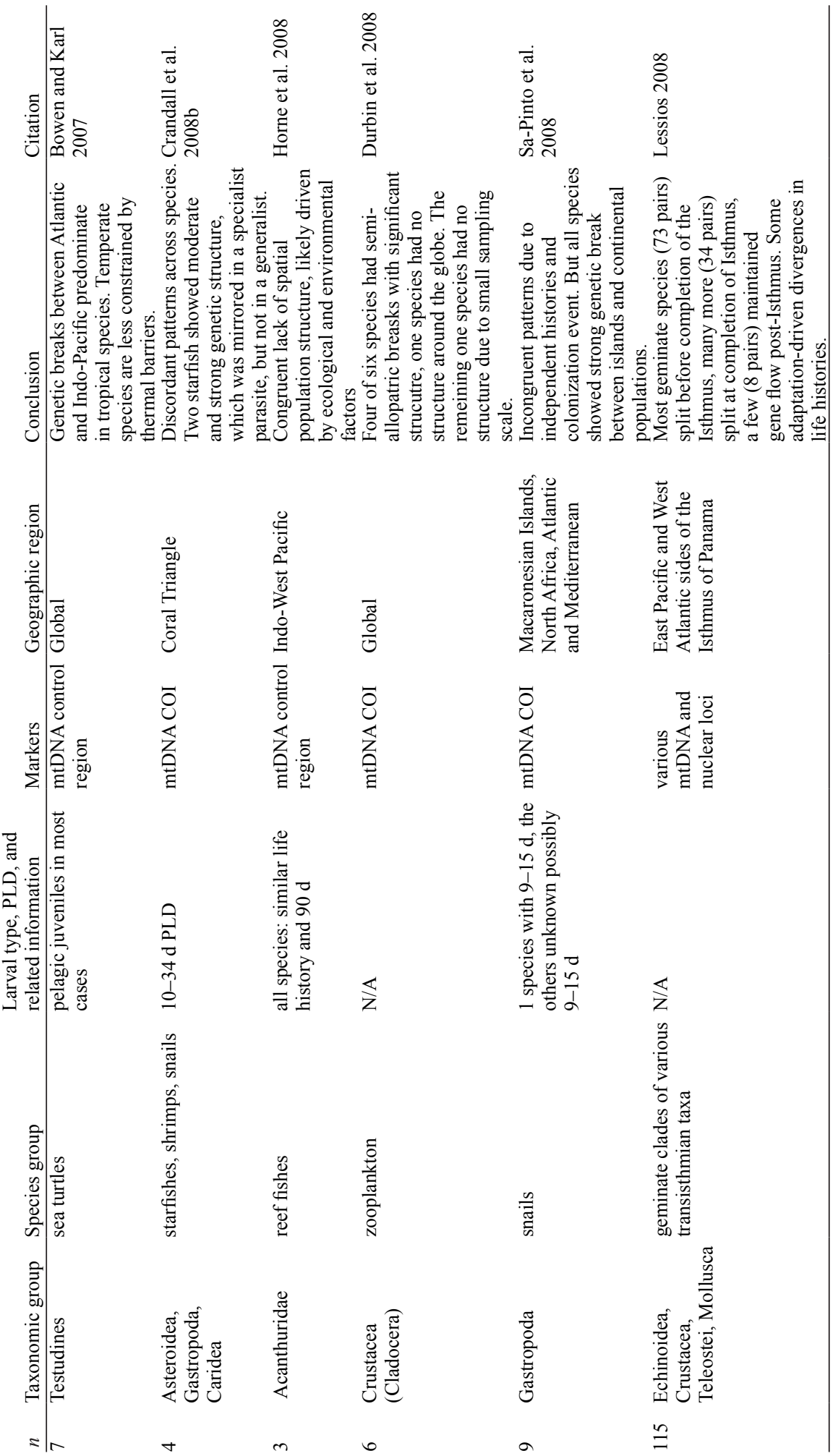




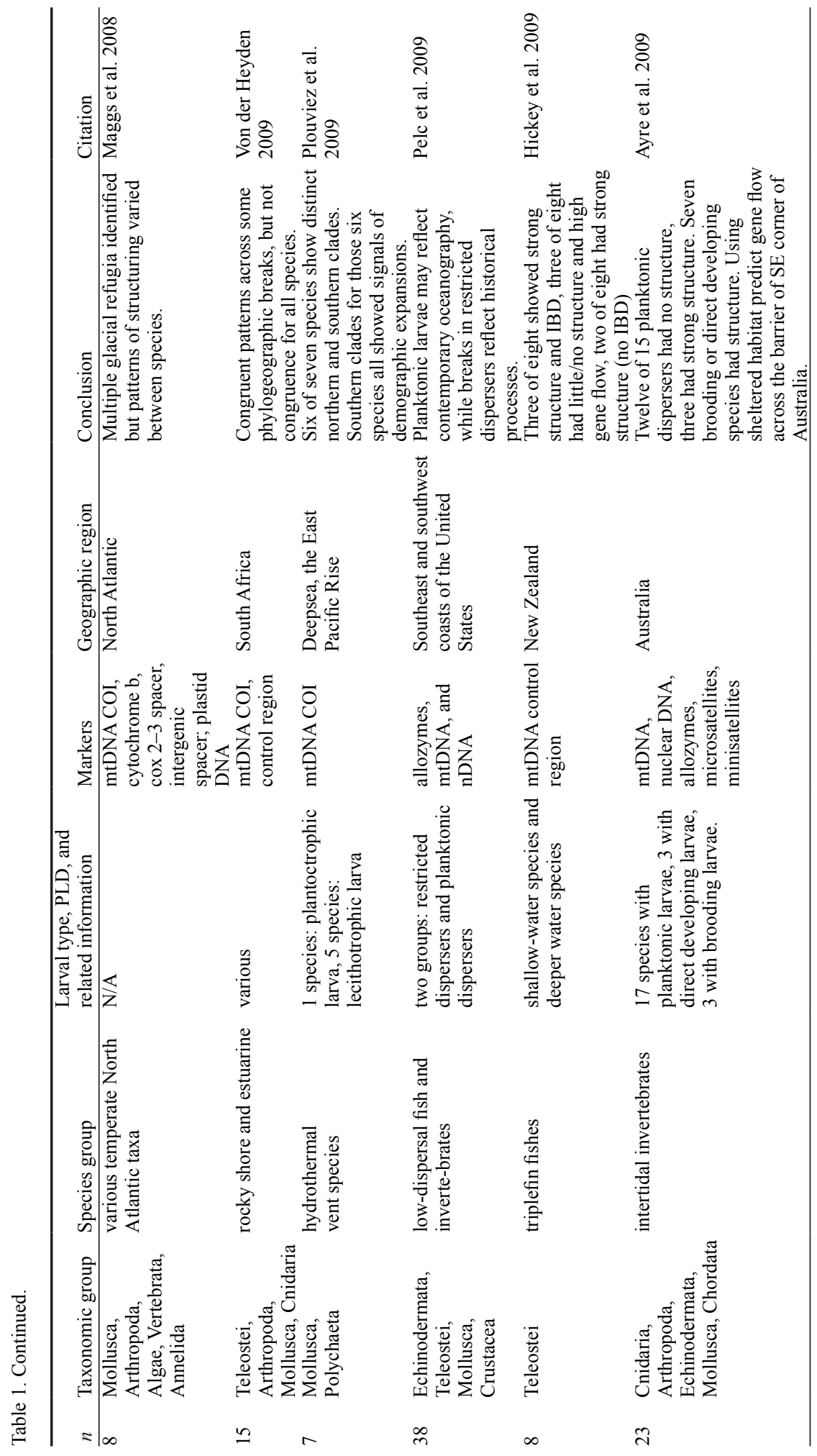




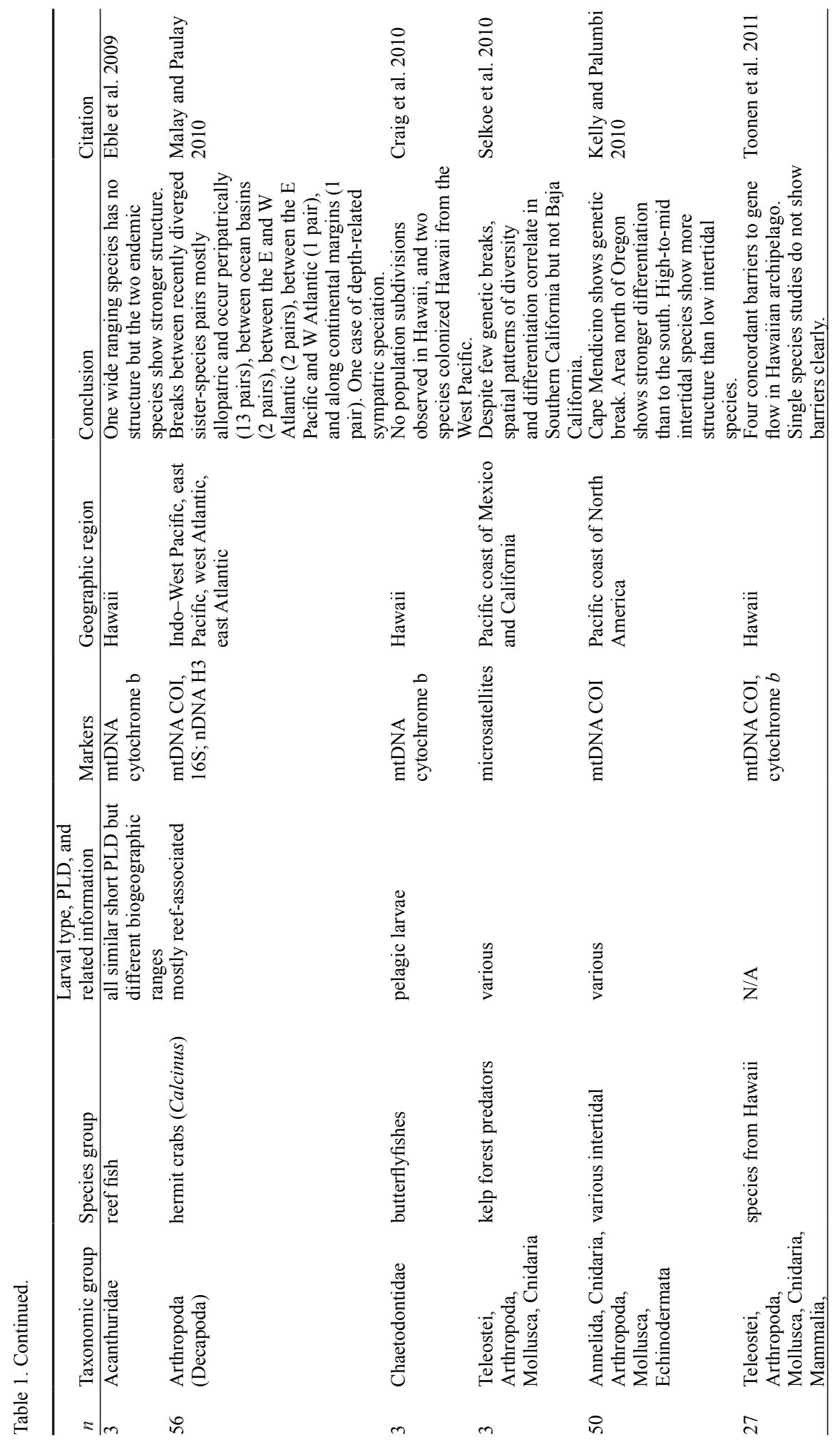




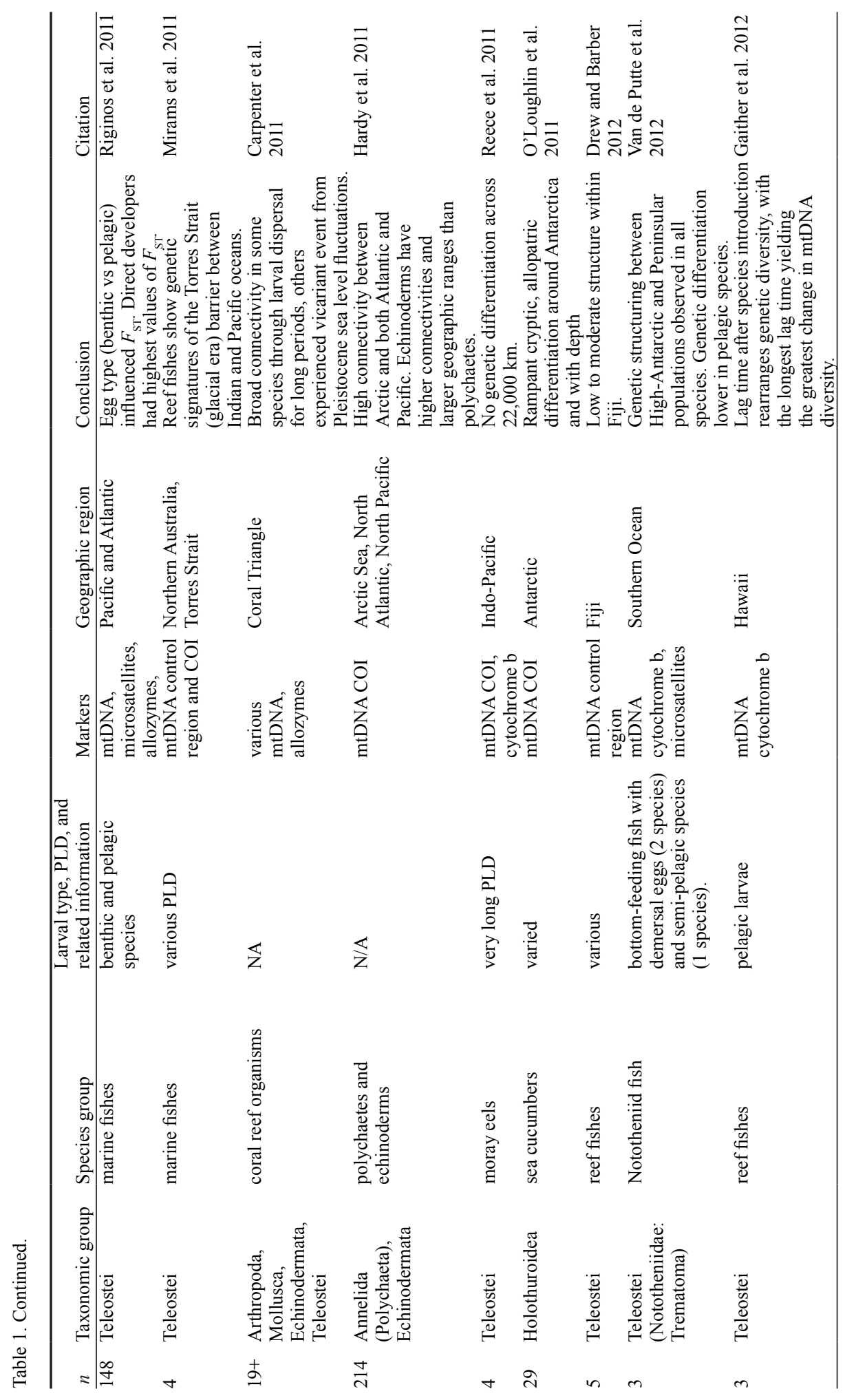




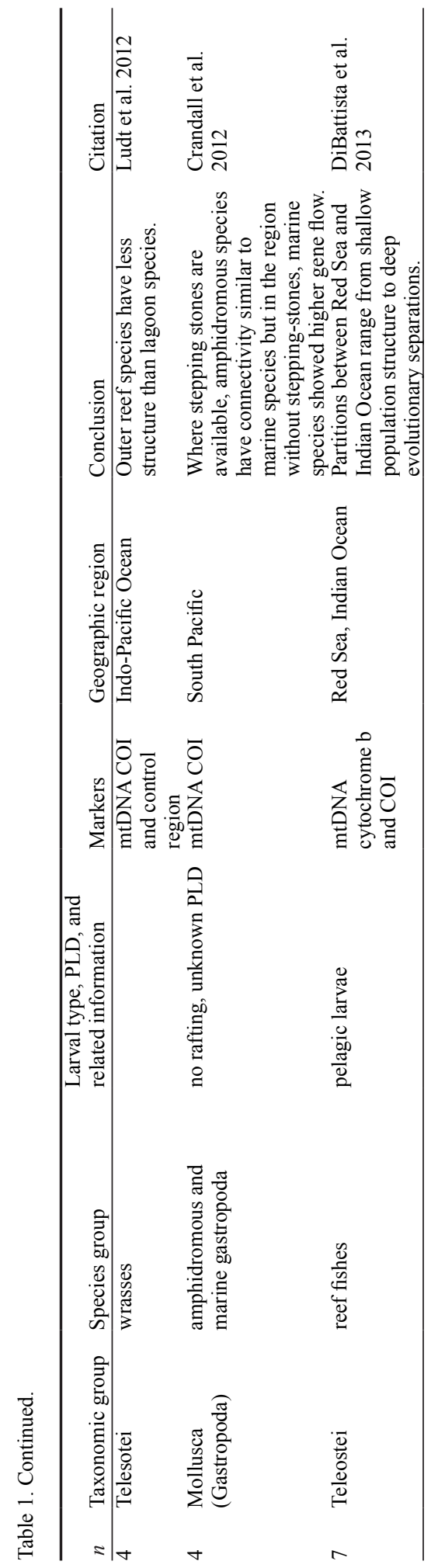


constraints. Furthermore, species of greater interest for management and conservation may be subject to tightly-focused studies. However, where possible, the comparisons of multiple co-distributed species are desirable to flesh out biogeographic history (Carpenter et al. 2011, Toonen et al. 2011). For example, congruent phylogeographic breaks among multiple species may indicate a shared history, especially when found at the boundaries of biogeographic provinces (Avise 1992, Dawson 2001, Wares et al. 2001, Bernardi et al. 2003, Barber et al. 2006, 2011; see Table 1).

The comparative advantage in phylogeography is that concordant patterns in multiple species may reveal shared evolutionary events. This concordance can apply across both geography (biogeographic barriers) and time (such as colonization of Hawaii; Craig et al. 2009). Many examples are provided in Table 1. The NESCent working group recognized that one of the central challenges of contemporary phylogeography is the dearth of analytical tools for comparing and combining analyses of separate species. Toonen et al. (2011) used a simple chi-square test for detecting where congruent genetic breaks appear more often than at random along the Hawaiian archipelago for 27 reef species. Barber et al. (2011) found strong concordant phylogeographic patterns in 14 species of mantis shrimp in Indonesia. Carpenter et al. (2011) identified multiple regions of the Coral Triangle that have congruent breaks in mtDNA data across fish and invertebrates. Kelly and Palumbi (2010) used an assortment of 50 intertidal data sets from the west coast of North American to discern a trend toward stronger genetic partitioning north of Oregon vs the south. However, none of these studies were able to make strong biogeographical inferences based on a comprehensive statistical model (see Pelc et al. 2009). One way to address this limitation is through new statistical methods to examine cross-community trends in spatial genetic differentiation across codistributed species (Hickerson and Meyer 2008, Mirams et al. 2010, KA Selkoe et al. unpubl data).

As the field accumulates spatial genetic data sets at ever increasing rates, there will be more opportunity to build on these important steps toward extending our conceptual and empirical understanding of connectivity. These will include more sophisticated statistical frameworks that combine individual data sets to leverage statistical power and test predictions about the historical, environmental, taxonomic, and ecological mechanisms underlying shared and divergent patterns. Examples of promising avenues include application of Hierarchical Approximate Bayesian Computation (HABC) for phylogeography that can use individual taxa as units of replication; individual coalescent models for each species can be used to parameterize larger models of community dynamics (Hickerson and Meyer 2008, Carnaval et al. 2009, Beaumont 2010). HABC methods analyze all the phylogeographic data sets at once to make across taxon-pair inferences about biogeographic processes while explicitly allowing for uncertainty in the demographic differences within each taxon-pair (Hickerson and Meyer 2008). Therefore, HABC approaches are expected to provide a bridge linking comparative phylogeography with community ecology (Hickerson and Meyer 2008). On another front, population graph approaches can build congruence networks based on two or more spatial genetic data sets (Dyer et al. 2010). Population graphs connect the population pairs exchanging migrants in the network by edges whose length is inversely proportional to the genetic covariance between the populations (Dyer and Nason 2004). Because conditional genetic distance (cGD) in a population graph is based upon the differences in genetic covariation associated with both direct and indirect gene flow among populations, cGD should be 
more sensitive than conventional pairwise $F_{\mathrm{ST}}$ and better suited for landscape genetics (Dyer et al. 2010). Another promising avenue incorporating genetic data sets for conservation planning would be Bayesian Belief Network analysis (BBNs), which can overcome variable sampling coverage across data sets to build a single probability distribution (e.g., Kininmonth et al. 2010a,b). BBNs consist of qualitative and quantitative components. The former is a Directed Acyclic Graph (DAG), which denotes dependencies and independencies between the variables that represent the modeled system. The latter component is Conditional Probability Tables (CPTs), which denote the strengths of the relationship among the variables (Aguilera et al. 2011). The advantage of a BBN is that uncertainties as well as expert opinions can be incorporated, while the strength of the causal relations between the networks variables can be quantified through conditional probabilities (Landuyt et al. 2013). BBNs are now being used for evidence-based conservation management of both aquatic and terrestrial ecosystems (reviewed by Landuyt et al. 2013).

In discussing the greatest gaps in sampling design, a consensus quickly emerged around the need for thorough geographic sampling. The literature contains many examples where species ranges (or evolutionary lineages within species) exceed the boundaries defined by faunal breaks, and sparse sampling across vast geographic regions can miss these important cases. For example, different species show different distributions, levels of divergence, and levels and patterns of introgression at the major faunal break between the Indian and Pacific basins. The level of exchange between Pacific and Indian basins fluctuates during each glacial cycle, causing some lineages to diverge and then come into renewed contact (Benzie 1999a). Are these sister lineages hybridizing? Hobbs et al. (2009) and Montanari et al. (2011) demonstrated that there are focal points of hybridization. However, the Coral Triangle (Indo-MalayPhilippines archipelago) may also be the world's largest suture zone, where clines between genetic lineages may slosh about such that no single geographic feature is the site of a distinct concordant break for most species in the region (Carpenter et al. 2011). Another important process in this region is range expansions resulting from periodic flooding of the Sunda and Sahul shelves adjacent to the Coral Triangle (Barber et al. 2002, Klanten et al. 2007, Crandall et al. 2008a, 2012a, DiBattista et al. 2012a). In particular, the more diverse and upstream Pacific assemblage seems to be expanding west and south into the Indian Ocean (Williams and Benzie 1997, 1998, Benzie 1999b, Lessios et al. 2001, Craig 2008, Drew and Barber 2009, Briggs and Bowen 2012, but with some exceptions, see Kochzius et al. 2009, Gaither and Rocha 2013). The conclusion is inescapable: dense sampling across species ranges is necessary to understand phylogeographic dynamics. Intense sampling in limited areas may uncover a faunal boundary, but the source of the genetic variation may originate beyond the sampled area.

\section{Don't Search for a Gold Mine by Digging Holes}

The great promise of genomic comparisons (Berner et al. 2008, Hohenlohe et al. 2011, Rocha et al. 2013, Willette et al. 2014) and occasional perils (Roesti et al. 2012) continue to unfold. As genomic data become available, DNA segments can be parsed across selected and neutral panels of loci, and will likely reveal the main forces of local adaptation at work at the species and community levels (Bertness and Gaines 1993, Sotka 2005, Gaggiotti et al. 2009, Nielsen et al. 2009, Sanford and Kelly 2011). 
However for the immediate future, it is infeasible to conduct genome-scale comparisons on hundreds to thousands of specimens. The technology is widely available, but the analytical software is not. The broad accessibility of genomic tools is creating a rush where researchers are abandoning tried and true tools in favor of novel genomic methods. However, the indiscriminate application of genomics is like randomly digging holes to find a gold mine. It is far more efficient to first find signs of gold, whether through insights from morphology, mtDNA patterns, or discordance between loci, and follow up with more comprehensive genomic approaches when emerging patterns warrant.

In all areas of wildlife genetics, there is a long history of casting off well-established methods for the next technology. The push to incorporate next-generation sequencing methods in phylogeography is leading to the systematic abandonment of previous techniques, a process endorsed by both funding agencies and editorial policies where journals prohibit single marker studies and/or impose requirements for minimal numbers of loci. Funding agencies prioritize genomic research over field studies. The NESCent working group agreed that methods should be chosen based on their cost and ability to address a hypothesis, rather than their novelty. In the medical field it is widely accepted that a thermometer or stethoscope are still invaluable tools, despite the availability of more technologically advanced tools like MRI and CAT Scanners, yet phylogeographers continually cast aside valuable tools in favor of the next big thing. Given limited resources, a data set that samples populations of many species for a single mtDNA locus may be most appropriate for hypotheses focused on comparative and community level patterns. Hypotheses should dictate methods, not vice versa.

Recent years have seen several papers challenging the utility of mtDNA, citing limited examples of selective sweeps, non-uniparental inheritance, and non-clonality (e.g., Bazin et al. 2006, Galtier et al. 2009). However, the ability to find limited exceptions to typical mitochondrial evolution and inheritance among the thousands of published studies should provide more solace than concern regarding the ability of this marker to faithfully record evolutionary history (Wares et al. 2006, Karl et al. 2012). Despite assertions to the contrary, evidence of noise and/or bias in spatial genetic patterns associated with mtDNA is not overwhelming; a review of more than 48 avian studies found phylogenetic estimates from mtDNA vs microsatellite markers were overwhelmingly comparable (Zink and Barrowclough 2008), and a recent review of nuclear-mitochondrial discordance in animals found a low level of incongruence (<18\%: Toews and Brelsford 2012). Similar results from marine organisms indicate that mtDNA will often (but not always) be the first locus to show genetic structure due to its smaller effective population size (Timm et al. 2012, DeBoer et al 2014a).

It is important to recognize that one or a few loci may be a poor representation of the entire genome. However, the power to detect shared patterns in single marker studies comes from replication across species rather than multiple loci within species. The consensus among the NESCent working group is that comparative phylogeography should contain an initial survey with a simple set of genetic markers; mtDNA sequences in many cases, but also nuclear introns, microsatellites, or single nucleotide polymorphisms (SNPs) as appropriate for the questions being addressed (Fig. 1). One of the most important insights to be gained from the initial surveys is to pinpoint the regions, zones, taxa, or populations that contain the highest variance 


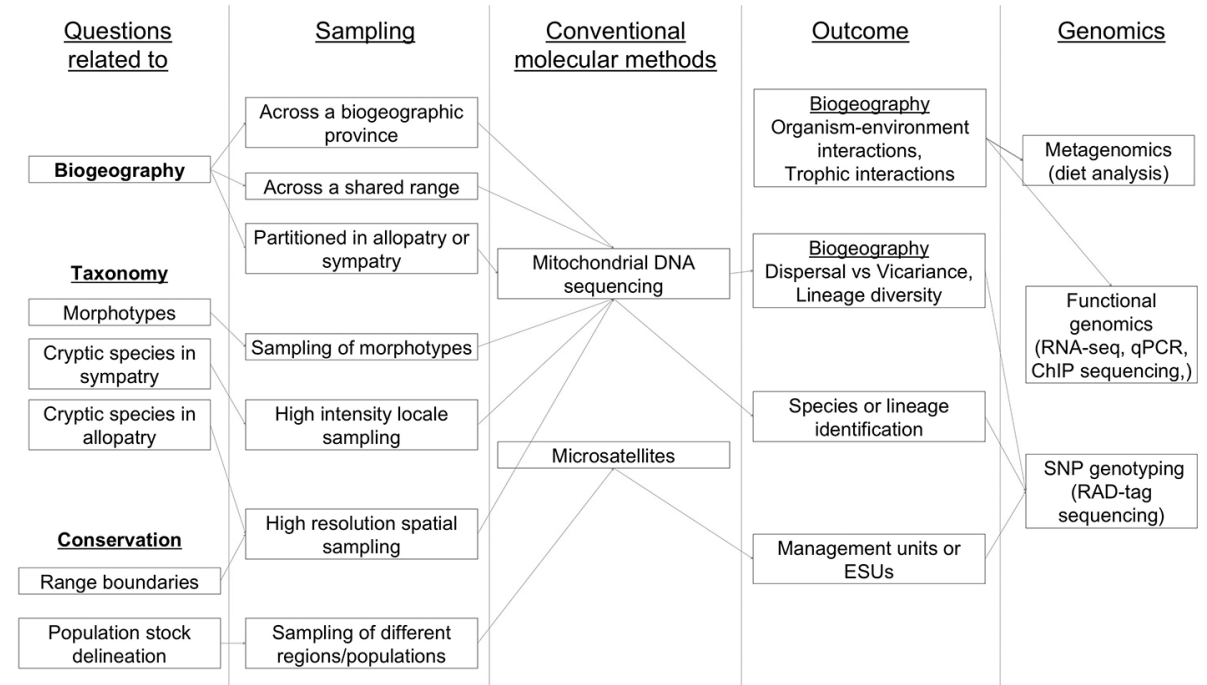

Figure 1. Schematic chart showing the progression of phylogeographic studies from initial survey with a simple genetic marker (usually mtDNA) through to evolutionary and biogeographic conclusions, and subsequent genomic investigations. For simplicity this diagram is confined to animal genomes, but the haploid chloroplast genome in plants could be substituted for mtDNA in the progression of approaches. While genomic approaches provide more data, they should be used selectively, as substantial resources are required for subsequent bioinformatics. While next-gen sequencing is still expensive in most parts of the world, the cost per informative locus is likely to be much lower. General estimates suggest that while starting costs (equipment and setup) is considerable, the per base pair cost of next-gen sequencing can be 1/1000th the cost of conventional sequencing or lower. Single nucleotide polymorphism (SNP) genotyping is widely used for population genetic and phylogeographic studies. In particular, genomic approaches can be helpful in uncovering cryptic species diversity and in community phylogeography. Functional genomics can extend beyond examining differentiation at neutral loci to answer questions about selection and adaptation. Recently, RNA-seq or whole transcriptome sequencing has been used for this purpose. In addition, SNPs can also be used for behavioral research and pedigree resolution, and metagenomics is used for sequencing environmental samples, including diet analysis.

or extremes of the genetic spectrum for further investigation. Moreover, before detailed genomic studies of selection and local adaptation can be undertaken, it is critical to understand (and be able to model) the underlying population structure and demographic history of the population under investigation (Williamson et al. 2005, Excoffier et al. 2009).

\section{Moving from Simple Genetic Markers to Genomics}

These "unplugged" surveys (using single or a few genetic markers prior to genomics) across a broad range of species and geography provide signposts for further genetic explorations in select taxa and areas (Fig. 1). How does the phylogeographer then incorporate genomics into comparative geographic surveys? By focusing on the potential "gold mines" identified in initial surveys. Here we consider five general outcomes, and the genomic explorations that may be mandated by these results.

1. Concordant Patterns Among Species.-Concordant patterns among species indicate shared biogeographical barriers or common history (Avise 2000, Rocha et al. 2002, Hickerson et al. 2010). One of the most exciting frontiers in this respect is the 
shift from single-species conservation programs to ecosystem-level management of marine resources. Comparative phylogeography can be valuable in this initiative, by defining the boundaries between marine assemblages that are shared across taxonomic and trophic categories. For example, Toonen et al. (2011) documented genetic breaks in the Hawaiian Archipelago that are shared between mollusks, corals, echinoderms, fishes, and marine mammals. The spatial scale of genetic structuring tends to be smaller in the $600-\mathrm{km}$ Main Hawaiian Islands than the $1500-\mathrm{km}$ Northwest Hawaiian Islands. Thus, a follow-up study (possibly using SNPs, microsatellites, or other more variable loci) would focus on heavier sampling in the main islands and sparser sampling in the remote northwest to further capture spatial patterns of structuring. Given the challenges in cost, technology, and bioinformatics still facing genomic analyses, efficiency in the number and locations of samples is crucial. With this more informed sampling design, getting appropriate coverage with genomic scale markers is more feasible. Note that concordant patterns and processes are not always obvious from a glance at a haplotype network or a set of pie charts. Crandall et al. (2012b) found that a biophysical model of larval dispersal among South Pacific archipelagos provided the best explanation for mitochondrial data in four gastropod species, despite qualitative differences in the structure and distribution of their haplotype networks.

\section{Non-concordant Patterns Among Species or Loci.-Non-concordant patterns} among species or loci may be the stepping off point for genome-wide studies, as well as ecological or morphological surveys. Variation in mating systems, fertilization biology, larval biology, population size, ecology, etc. all influence distributions and connectivity. The mode and scale of dispersal are known to have a broad impact on genetic structuring, speciation, and resulting diversity pattern (Paulay and Meyer 2006, Malay and Paulay 2009). Egg size, mode of development, and pelagic period can evolve rapidly and often differ among closely related species (Schulze et al. 2000, Collin 2004, Marko and Moran 2002, Hart et al. 2011, Puritz et al. 2012b). Aside from these ecological effects, the large effective population sizes of most marine species may obscure events such as recent speciation and range expansion, due to non-equilibrium allele frequencies, incomplete lineage sorting, and non-concordant patterns among loci. Under such non-equilibrium processes, the use of equilibrium models can inflate estimates of gene flow between populations or closely related species (Marko and Hart 2011). Therefore using only a few neutral loci may fail to catch the "true" patterns of species boundaries and/or population structure. Gamete recognition loci in free spawners and mating systems in internal fertilizers test and influence emerging species boundaries, impact the tempo and scale of speciation (Hellberg et al. 2000, Landry et al. 2003), and can yield different evolutionary dynamics among related taxa (Rocha-Olivares et al. 2001, Palumbi and Lessios 2005). While past studies have tested for evidence of selection at specific loci involved in fertilization (Lessios 2011), sensory perception (Seehausen et al. 2008), and bioluminescence (Feder and Velez 2009), phylogenomic approaches are allowing broad evaluation of which loci are under selection, thus permitting the evaluation of the importance of reproductive and ecological factors in speciation (Excoffier et al. 2009, Gagnaire et al. 2011, Bird et al. 2012, Deagle et al. 2012, Pespeni et al. 2012).

\section{Discordance Between Molecular and Morphological Differentiation.-} Discordance between molecular and morphological differentiation can provide 
another appropriate starting point for genomics. Comparative studies can distinguish adaptive and non-adaptive radiation (i.e., ecological opportunity). While evolutionary radiations can be inferred from temporal patterns of diversification (exemplified by "early bursts"), adaptive radiations are associated with ecological opportunity (Losos 2010), which is often revealed through selection on morphological traits. For example, color is a very important taxonomic character in many groups, and can indicate underlying genetic differentiation (e.g., Meyer et al. 2005, Drew et al. 2008, Timm et al. 2008, Malay and Paulay 2009). However, coloration is not always a reliable taxonomic character; the brightly-colored pygmy angelfishes (Centropyge spp.) have taxonomic divisions based on color patterns that do not align with genetic partitions (DiBattista et al. 2012b). Conversely, a phylogeographic survey of bonefishes (genus Albula) using the same mtDNA marker revealed deeply divergent genetic lineages that were almost indistinguishable with external morphology (Bowen et al. 2007). A combination of these patterns is also found in the hamlet (genus Hypoplectrus) species flock in the Caribbean (Puebla et al. 2007). These cases raised evolutionary questions that can now be addressed using genome-wide techniques, but those questions might never have surfaced without the initial single marker studies.

4. Geographic Contexts of Speciation.-Comparative studies can explore the relative importance of allopatric, parapatric, and sympatric speciation, providing insights into the causes of diversification (Rocha and Bowen 2008, Bird et al. 2011, Dawson et al. 2012). For example, younger species with non-overlapping distributions on either side of a biogeographic barrier and range overlap by older species are signatures expected from allopatric speciation followed by secondary contact. Multiple species with coincident ranges bounded by barriers are also the consequence of divergence in geographic isolation (Jordan 1904, Mayr 1954). Conversely, sympatric speciation can arise anywhere within a species range and thus produce a pattern in which geographic overlap bears no relation to potential barriers. Members of the gastropod genus Lunella include sympatric species along coastlines, whereas species distributed in two-dimensional island arrays are allopatric (Williams et al. 2011). In this case, sympatric species showed greater phenotypic diversity than allopatric species, indicating that cryptic species are more likely to occur in taxa with allopatric distributions. However these expectations can be confounded by unequal rates of accumulation of reproductive isolation (Palumbi and Lessios 2005) or by rapid dispersal that erases traces of the actual point in space where new species arose; nevertheless, they are useful guides for the causes of speciation events, particularly if they are duplicated in multiple unrelated taxa. Allopatric species complexes are common in the Indo-Pacific region, and future taxonomic and biogeographic studies could benefit from focusing on low dispersal species in this region. Here again, the resolution of markers available today can provide critical insights, but genome-wide studies can provide resolution, especially in species complexes with fuzzy boundaries (Forsman et al. 2010, Nosil and Feder 2012, Radwan and Babik 2012, Stat et al. 2012, Rocha et al. 2013).

5. Origins of Marine Biodiversity.-Patterns of origination and dispersal have begun to appear through phylogeographic studies in recent years (Palumbi 1997, Eble et al. 2011, Bowen et al. 2013, Cowman and Bellwood 2013, Gaither and Rocha 2013, Crandall et al. 2014). The Center of Origin hypothesis (Ekman 1953) to explain biodiversity hotspots was criticized for lacking a plausible process for speciation within 
the Coral Triangle (Jokiel and Martinelli 1992). Recent comparative phylogeography studies in this region highlight the role of Pleistocene sea level fluctuations and the Halmahera Eddy in driving lineage diversification (Barber et al. 2006, Crandall et al. 2008a, Barber et al. 2011). While these patterns are clear in some species (e.g., Barber et al. 2002, DeBoer et al. 2008, 2014b), they can be less clear in others. For example, Vogler et al. (2008) demonstrated that the crown of thorns sea star, Acanthaster planci (Linnaeus, 1758), is likely a species complex and multiple "species" and haplogroups are distributed across the Coral Triangle. However, it is unclear whether overlapping distributions in the Coral Triangle result from secondary contact (with potential hybridization) following allopatric speciation, or whether speciation resulted from natural selection in sympatry. Similarly surveys of coral-feeding nudibranchs across the Pacific (Faucci et al. 2007) and gastropods in the Coral Triangle (Simmonds et al. unpubl data) have revealed that genetic lineages are associated with feeding preferences, rather than geography, indicating sympatric speciation. In the above cases, mtDNA provided critical insights, but genome wide studies are essential to fully understand evolutionary histories by distinguishing between neutral and selective divergence and testing for introgression.

\section{ECOLOGICALLY-GROUNDED HyPOTHESES}

The five general patterns described above (discordance between loci or data sets, geographic distributions and origins, species dispersal) provide not only signposts toward further exploration of the genome, they also can send the perceptive researcher back into the water for additional sampling and study. To understand the complex process of speciation in the sea, it is important to distinguish between populations that are differentiating as a result of selection (potentially despite exchanging migrants) from those that differentiate primarily through genetic drift in geographic isolation. Marine phylogeography has a traditional emphasis on geography, but increasingly the study design is focused on ecological partitions (Munday et al. 2004, Rocha et al. 2005, Choat 2006, Selkoe et al. 2010). When there are evolutionary issues such as ecological divergence between closely related species, there is good reason to explore further into the genome as well as the ocean.

Genomic scale studies will enable us to ask questions about the feedbacks between ecological and evolutionary phenomena. For instance, the Marquesas are especially interesting for genetic studies, as they have both oceanographic isolation and ecological differences from the adjacent Society Islands, including upwelling, variable temperatures, and little coral cover (Randall 2001, Hickerson and Meyer 2008). The Marquesas are also genetically distinct from the Society Islands in six of eight species surveyed to date (Planes and Fauvelot 2002, Gaither et al. 2010, Crandall et al. 2012, Szabo et al. 2014) and harbor the third highest endemism rate in the Pacific Ocean (Briggs and Bowen 2012). Is geographical concordance between population genetic and biogeographic evolutionary patterns the norm? In other words, do areas with high levels of genetic diversity and structure tend to have high rates of endemism? Are the same ecological drivers behind both phenomena? These are exciting frontiers in marine phylogeography. The availability of genomic sequencing combined with newly available environmental databases for marine ecosystems (Sbrocco and Barber 2013) makes it possible to simultaneously examine the variability of neutral and selected regions of the genome across geographic and ecological parameters. 


\section{Combining Evolution and Ecology to Understand Species Richness} PATTERNS

Traditionally, studies either have explored temporal patterns of diversification from a biogeographic perspective, or spatial patterns in relation to parameters such as environment, area, and range. Wiens and Graham (2005) proposed a niche conservatism model based on phylogenetic history to explain contemporary patterns of species richness, thereby making a case for combining ecology and evolution. Rahbek et al. (2007) developed models combining range and environment in predictions of richness patterns at continental scales, using a bird data set from South America. Gotelli et al. (2009) presented a theoretical framework for modeling richness, combining evolution and ecology. Such models require fine scale understanding of species boundaries and range, as well as diversification rates, which can only be inferred from phylogeographic and phylogenetic data.

\section{Conclusion: Not the End of History}

The historian Francis Fukuyama famously remarked that the end of the Cold War could be the end of history, based on a perceived stabilization of the world order (Fukuyama 1992). Karl Marx made a similar claim in 1859 based on the presumed supremacy of communism. It did not happen then, and it will not happen in phylogeography now. However, the field may be reaching a more stable state after two decades of swiftly changing approaches. With entire genomes in hand, we will soon have the capacity to evaluate the relative power and utility of different markers, and determine which loci are the key drivers of marine diversification.

The optimal study design we endorse for comparative phylogeography requires the surveys of hundreds of specimens, range-wide coverage where possible, across 10, 20, or more species. This should include a field effort commensurate with the issues, an initial survey with simple genetic markers such as mtDNA, microsatellites, or SNPs, followed by judicious applications of genomics when necessary. Before gigabases of population genomic data are collected, it is essential that the investigator consider the hypotheses being tested, as well as the data requirements and limitations of the model that will be used for inference. Population (and management) level issues for individual species are amenable to applications of SNPs and microsatellites, evolutionary issues can be pursued at the appropriate level of nDNA analysis. If the question is phylogenetic distinctiveness, fewer loci are needed than in the quest for loci under selection.

An obvious and valid criticism of using mtDNA for an initial sweep is that it would miss some evolutionary patterns present in the nuclear genome (Eytan and Hellberg 2010, DiBattista et al. 2012b). As noted earlier, while the caveat of mitochondrialnuclear discord is routinely raised as a criticism of single-locus studies, such cases are rare (Karl et al. 2012, Toews and Brelsford 2012). While introgression and paralogy can impact mtDNA analyses as that of any single marker analysis, error rates in most groups are low ( $<2 \%$ in large mollusk data sets; Meyer and Paulay 2005), with perhaps the exception of taxa prone to nuclear pseudogenes of mitochondrial origin (NUMTs; Williams and Knowlton 2001). Furthermore, the pitfalls of mtDNA studies are fairly well known and can usually be recognized and tested, while the drawbacks of nuclear or genomic approaches are still being discovered. Therefore, 
mtDNA still provides the most versatile tool for taxonomically and geographically broad-scale studies because of its ease of amplification across taxa, level of resolution, and low cost. The more broadly used nuclear markers often do not distinguish closely related species (Andrews et al. 2013), while microsatellites lack phylogenetic breadth in application. A major promise of genomic approaches is developing access to an abundance of nuclear markers (Etter et al. 2011, Faircloth et al. 2012, Lemmon and Lemmon 2012, Rocha et al. 2013), perhaps with the eventual goal of a core set of nuclear markers applicable across a wide range of species.

Single locus studies offer another advantage in providing standardized DNA sequence data sets that can be shared between laboratories, and augmented with new data. The sea turtle research community has exploited this advantage to allow comparisons between new and existing data sets based on sequences of the mtDNA control region. When new haplotypes are reported, the sequences are archived in a database maintained by the Archie Carr Center for Sea Turtle Research (http:// accstr.ufl.edu/resources/mtdna-sequences/). Researchers can use this archive to link haplotypes observed on nesting beaches to haplotypes observed in distant feeding aggregates, greatly accelerating the scientific foundations for protection in international waters (Bowen and Karl 2007, Bjorndal and Bolten 2008). For additional examples of pre-existing data sets, see Keyes et al. (2014). Comparable DNA data sets also allow the barcoding that has emerged as a powerful tool, using the same marker in many taxa permits matching of unknowns against a library of accumulated sequences (Hebert et al 2003). Emerging metagenomic approaches are now taking advantage of such barcode libraries to evaluate community diversity (e.g., Leray et al 2013).

Another major reason for keeping single locus markers in the phylogeographer's tool kit is to advance marine phylogeography regardless of economic conditions (Barrowclough and Zink 2009). The vast majority of the world's biodiversity hotspots are centered in developing countries (Roberts et al. 2002) that have limited funding for basic research. While next generation sequencing methods will undoubtedly decrease greatly in cost, it may still be cost-prohibitive in many science communities. Simple mtDNA studies are still effective in addressing key evolutionary and conservation questions (DeBoer et al. 2014a).

Finally, harking back to our roots in morphology and field observations, the phylogeographer should not forget the value of knowing the organisms intimately. This has been borne out countless times in our field, as the astute marine phylogeographer sees a known organism in a new location for the first time, and says "that looks different". That "different" organism is supposed to be the same species as elsewhere but has a new shape or color, a distinctive behavior, or a different host (Rocha 2004, Faucci et al. 2007, DiBattista et al. 2013). Phylogeographic studies based on such observations are fueling a revolution in the discovery of cryptic marine diversity, and providing foundations of further evolutionary studies (Gittenberger and Gittenberger 2011, O'Loughlin et al 2011). Good naturalists also notice differences in the diversity, distributional, or abundance trends across environments and taxa, which can guide selection of species targeted to test particular hypotheses. For example the rarity and low diversity of Calcinus hermit crabs or certain land crabs in the Coral Triangle indicates that ecological restriction to oceanic regions is an important selective force in some taxa that can lead to inverse patterns of diversity (Malay and Paulay 2010, Paulay and Starmer 2011). Indeed it is fascinating when these field observations lead to the descriptions of new species or novel evolutionary lineages. However, it can be 
equally interesting when the differences observed in the field do not yet translate into genetic partitions at neutral loci (DiBattista et al. 2012b, Baums et al. 2013). Regardless of the outcome, a primary challenge of our day is to fit the plethora of genomic data into phylogeographic conclusions. The emphasis on genomics is apparent in granting trends, as funding has shifted yet again. Our emphasis here is on the less appreciated truth that a strong field component, and adequate sampling, is the universal foundation for robust marine phylogeography.

\section{ACKNOWLEDGMENTS}

We thank the National Evolutionary Synthesis Center at Duke University for hosting the meeting "Molecular Ecology and Evolution of the Indo-Pacific" that produced this paper. That meeting was funded by a National Science Foundation grant to ED Crandall and C Riginos. We thank special editor C Riginos, U Ramakrishnan, and an anonymous reviewer for comments that improved the manuscript.

\section{Literature Cited}

Aguilera PA, Fernández A, Fernández R, Rumí R, Salmerón A. 2011. Bayesian networks in environmental modelling. Environ Model Softw. 26:1376-1388. http://dx.doi.org/10.1016/j. envsoft.2011.06.004

Andrews KR, Perrin WF, Oremus M, Karczmarski L, Bowen BW, Puritz JB, Toonen RJ. 2013. The evolving male: spinner dolphin (Stenella longirostris) ecotypes are divergent at Y chromosome but not mtDNA or autosomal markers. Mol Ecol. 22:2408-2423. PMid:23551274. http://dx.doi.org/10.1111/mec.12193

Audzijonyte A, Daneliya ME, Vainola R. 2006. Comparative phylogeography of Ponto-Caspian mysid crustaceans: isolation and exchange among dynamic inland sea basins. Mol Ecol. 15:2969-2984. PMid:16911214. http://dx.doi.org/10.1111/j.1365-294X.2006.03018.X

Avise JC. 1992. Molecular population structure and the biogeographic history of a regional fauna: a case history with lessons for conservation biology. Oikos. 63:62-76. http://dx.doi. org/10.2307/3545516

Avise JC. 2000. Phylogeography: the history and formation of species. Cambridge MA: Harvard University Press. ISBN 0-674-66638-0.

Avise JC, Lansman RA, Shade RO. 1979. The use of restriction endonucleases to measure mitochondrial DNA sequence relatedness in natural populations. I. Population structure and evolution in the genus Peromyscus. Genetics. 92:279-295. PMid:499767. PMCid:PMC1213949.

Avise JC, Arnold J, Ball RM Jr, Bermingham E, Lamb T, Neigel JE, Reeb CA, Saunders NC. 1987. Intraspecific phylogeography: the mitochondrial DNA bridge between population genetics and systematics. Ann Rev Ecol System. 18:489-522.

Ayre DJ, Hughes TP. 2000. Genotypic diversity and gene flow in brooding and spawning corals along the Great Barrier Reef, Australia. Evolution. 54:1590-1605. PMid:11108587.

Ayre DJ, Hughes TP. 2004. Climate change, genotypic diversity, and gene flow in reef building corals. Ecol Lett. 7:273-278. http://dx.doi.org/10.1111/j.1461-0248.2004.00585.x

Ayre DJ, Minchinton TE, Perrin C. 2009. Does life history predict past and current connectivity for rocky intertidal invertebrates across a marine biogeographic barrier? Mol Ecol. 18:1887-1903. PMid:19434808. http://dx.doi.org/10.1111/j.1365-294X.2009.04127.x

Barber PH, Palumbi SR, Erdmann MV, Moosa MK. 2002. Sharp genetic breaks among populations of a benthic marine crustacean indicate limited oceanic larval transport: patterns, cause, and consequence. Mol Ecol. 11:659-674. PMid:11972755. http://dx.doi. org/10.1046/j.1365-294X.2002.01468.x 
Barber PH, Erdmann MV, Palumbi SR. 2006. Comparative phylogeography of three codistributed stomatopods: origins and timing of regional lineage diversification in the coral triangle. Evolution. 60:1825-1839. PMid:17089967.

Barber PH. 2009. The challenge of understanding the Coral Triangle biodiversity hotspot. J Biogeogr. 36:260-265. http://dx.doi.org/10.1111/j.1365-2699.2009.02198.x

Barber PH, Cheng SH, Erdmann MV, Tengardjaja K, Ambariyanto. 2011. Evolution and conservation of marine biodiversity in the Coral Triangle: insights from stomatopod Crustacea. Crustacean Issues. 19:129-156. http://dx.doi.org/10.1201/b11113-9

Barber PH, Ablan-Lagman MCA, Ambariyanto, Berlinck RGS, Cahyani D, Crandall ED, Ravago-Gotanco R, Juinio-Meñez MA, Mahardika IGN, Shanker K, et al. 2014. Advancing biodiversity research in developing countries: the need for a paradigm. Bull Mar Sci. 90:187-210. http://dx.doi.org/10.5343/bms.2012.1108

Bargelloni L, Alarcon JA, Alvarez MC, Penzo E, Magoulas A, Reis C, Patarnello T. 2003. Discord in the family Sparidae (Teleostei): divergent phylogeographical patterns across the Atlantic-Mediterranean divide. J Evol Biol. 16:1149-1158. PMid:14640406. http://dx.doi. org/10.1046/j.1420-9101.2003.00620.x

Barrowclough GF, Zink RM. 2009. Funds enough, and time: mtDNA, nuDNA and the discovery of divergence. Mol Ecol. 18:2934-2936. http://dx.doi.org/10.1111/j.1365-294X.2009.04271.x

Baums IB, Godwin S, Franklin EC, Carlon DB, Toonen RJ. 2013. Discordant population expansions in four species of coral-associated Pacific hermit crabs (Anomura: Diogenidae) linked to habitat availability resulting from sea-level change. J Biogeog. Online early.

Bay LK, Crozier RH, Caley MJ. 2006. The relationship between population genetic structure and pelagic larval duration in coral reef fishes on the Great Barrier Reef. Mar Biol. 149:1247-1256. http://dx.doi.org/10.1007/s00227-006-0276-6

Bazin E, Glemin S, Gaultier N. 2006. Population size does not influence mitochondrial genetic diversity in animals. Science. 312:570-572. PMid:16645093. http://dx.doi.org/10.1126/ science. 1122033

Beaumont MA. 2010. Approximate Bayesian computation in evolution and ecology. Ann Rev Ecol Evol System. 41:379-406. http://dx.doi.org/10.1146/annurev-ecolsys-102209-144621

Benzie JA. 1999a. Genetic structure of coral reef organisms: ghosts of dispersal past. Amer Zool. 39:131-145.

Benzie JA. 1999b. Major genetic differences between crown-of-thorns starfish (Acanthaster planci) populations in the Indian and Pacific oceans. Evolution. 53:1782-1795. http:// dx.doi.org/10.2307/2640440

Bermingham E, Moritz C. 1998. Comparative phylogeography: concepts and applications. Mol Ecol. 7:367-369. http://dx.doi.org/10.1046/j.1365-294x.1998.00424.x

Bernardi G, Findley L, Rocha-Olivares A. 2003. Vicariance and dispersal across Baja California in disjunct marine fish populations. Evolution. 57:1599-1609. PMid:12940364.

Berner D, Adams DC, Grandchamp A-C, Hendry AP. 2008. Natural selection drives patterns of lake-stream divergence in stickleback foraging morphology. J Evol Biol. 21:1653-1665. PMid:18691241. http://dx.doi.org/10.1111/j.1420-9101.2008.01583.x

Bertness MD, Gaines SD. 1993. Larval dispersal and local adaptation in acorn barnacles. Evolution. 47:316-320. http://dx.doi.org/10.2307/2410140

Bird CE, Holland BS, Bowen BW, Toonen RJ. 2007. Contrasting phylogeography in three endemic Hawaiian limpets (Cellana spp.) with similar life histories. Mol Ecol. 16:3173-3186. PMid:17651195. http://dx.doi.org/10.1111/j.1365-294X.2007.03385.X

Bird CE, Holland BS, Bowen BW, Toonen RJ. 2011. Diversification of endemic sympatric limpets (Cellana spp.) in the Hawaiian Archipelago. Mol Ecol. 20:2128-2141. PMid:21481050. http://dx.doi.org/10.1111/j.1365-294X.2011.05081.X

Bird CE, Fernandez-Silva 1, Skillings D), Toonen R). 2012. Sympatric speciation in the post "modern synthesis" era of evolutionary biology. Evol Biol. 39:158-180. http://dx.doi. org/10.1007/s11692-012-9183-6 
Bjorndal KA, Bolten AB. 2008. Annual variation in source contributions to a mixed stock: implications for quantifying connectivity. Mol Ecol 17:2185-2193. PMid:18373532. http:// dx.doi.org/10.1111/j.1365-294X.2008.03752.x

Bowen BW, Avise JC. 1990. The genetic structure of Atlantic and Gulf of Mexico populations of sea bass, menhaden, and sturgeon: the influence of zoogeographic factors and life history patterns. Mar Biol. 107:371-381. http://dx.doi.org/10.1007/BF01313418

Bowen BW, KarlSA. 2007. Population genetics and phylogeography of sea turtles. Mol Ecol. 16:4886-4907. PMid:17944856. http://dx.dol.org/10.1111/j.1365-294X.2007.03542.X

Bowen BW, KarI SA, Pfeiler E. 2007. Resolving evolutionary lineages and taxonomy of bonefishes (Albula spp.). In: Ault JS, editor. Biology and management of the world tarpon and bonefish fisheries. Boca Raton, FL: CRC Press. p. 147-154.

Bowen BW, Rocha LA, Toonen RJ, Karl SA, Craig MT, DiBattista JD, Eble JA, Gaither MR, Skillings D, Bird CE. 2013. Origins of tropical marine biodiversity. Trends Ecol Evol. 28:359-366. PMid:23453048. http://dx.doi.org/10.1016/j.tree.2013.01.018

Briggs JC, Bowen BW. 2012. A realignment of marine biogeographic provinces with particular reference to fish distributions. J Biogeogr. 39:12-30. http://dx.doi. org/10.1111/j.1365-2699.2011.02613.x

Briggs JC, Bowen BW. 2013. Evolutionary patterns: marine shelf habitat. J Biogeogr. 40:10231035. http://dx.doi.org/10.1111/jbi.12082

Brown WM, Wright JW. 1979. Mitochondria DNA and the origin of parthenogenesis in whiptail lizards (Cnemidophorus). Herpetol Rev. 6:70-71.

Carnaval AC, Hickerson MJ, Haddad CFB, Rodrigues MT, Moritz C. 2009. Stability predicts genetic diversity in the Brazilian Atlantic forest hotspot. Science. 323:785-789. PMid:19197066. http://dx.doi.org/10.1126/science.1166955

Carpenter KE, Barber PH, Crandall ED, Ablan-Lagman MCA, Ambariyanto G, Mahardika GN, Manjaji-Matsumoto BM, Juinio-Menez MA, Santos MD, Starger CJ, Toha AHA. 2011. Comparative phylogeography of the Coral Triangle and implications for marine management. J Mar Biol. 2011:396982. http://dx.doi.org/10.1155/2011/396982

Carstens B, Lemmon AR, Lemmon EM. 2012. The promises and pitfalls of next-generation sequencing data in phylogeography. System Biol. 61:713-715. PMid:22887013. http://dx.doi. org/10.1093/sysbio/sys050

Choat H. 2006. Phylogeography and reef fishes: bringing ecology back into the argument. J Biogeogr. 33:967-968. http://dx.doi.org/10.1111/j.1365-2699.2006.01524.x

Collin R. 2004. Phylogenetic effects, the loss of complex characters, and the evolution of development in calyptraeid gastropods. Evolution. 58:1488-1502. PMid:15341151.

Cowman PF, Bellwood DR. 2013. The historical biogeography of coral reef fishes: global patterns of origination and dispersal. J Biogeogr. 40:209-224. http://dx.doi.org/10.1111/ jbi.12003

Craig MT. 2008. The goldrim surgeonfish (Acanthurus nigricans; Acanthuridae) from Diego Garcia, Chagos Archipelago: first record for the central Indian Ocean. Zootaxa. 1850:65-68.

Craig MT, Eble J, Bowen BW. 2010. Origins, ages, and populations histories: comparative phylogeography of endemic Hawaiian butterflyfishes (genus Chaetodon). J Biogeogr. 37:21252136. http://dx.doi.org/10.1111/j.1365-2699.2010.02358.x

Crandall ED, Frey MA, Grosberg RK, Barber PH. 2008a. Contrasting demographic history and phylogeographical patterns in two Indo-Pacific gastropods. Mol Ecol. 17: 611-626. PMid:18179436. http://dx.doi.org/10.1111/j.1365-294X.2007.03600.X

Crandall ED, Jones ME, Munoz MM, Akinronbi B, Erdmann MV, Barber PH. 2008b. Comparative phylogeography of two seastars and their ectosymbionts within the Coral Triangle. Mol Ecol. 17:5276-5290. PMid:19067797. http://dx.doi.org/10.1111/j.1365-294X.2008.03995.X

Crandall ED, Sbrocco E], DeBoer TS, Barber PH, Carpenter KE. 2012a. Expansion dating: calibrating molecular clocks in marine species from expansions onto the Sunda Shelf following the last glacial maximum. Mol Biol Evol. 29:707-719. PMid:21926069. http://dx.doi. org $/ 10.1093 / \mathrm{molbev} / \mathrm{msr} 227$ 
Crandall ED, Treml EA, Barber PH. 2012b. Coalescent and biophysical models of steppingstone gene flow in neritid snails. Mol Ecol. 21:5579-5598. PMid:23050562. http://dx.doi. org $/ 10.1111 /$ mec. 12031

Crandall ED, Treml EA, Gleeson L, Liggins L, Yasuda N, Barber PH, Riginos CR. 2014. Return of the ghosts of dispersal past: historical spread and contemporary gene flow in the blue sea star Linckia laevigata. Bull Mar Sci. 90:399-425. http://dx.doi.org/10.5343/bms.2013.1052

Cristescu MEA, Hebert PDN, Onciu TM. 2003. Phylogeography of Ponto-Caspian crustaceans: a benthic-planktonic comparison. Mol Ecol. 12:985-996. PMid:12753217. http:// dx.doi.org/10.1046/j.1365-294X.2003.01801.x

Dawson MN. 2001. Phylogeography in coastal marine animals: a solution from California? J Biogeogr. 28:723-736. http://dx.doi.org/10.1046/j.1365-2699.2001.00572.x

Dawson MN. 2012. Parallel phylogeographic structure in ecologically similar sympatric sister taxa. Mol Ecol. 21:987-1004. PMid:22229665. http://dx.doi. org/10.1111/j.1365-294X.20П1.05417.X

Deagle BE, Jones FC, Chan YF, Absher DM, Kingsley DM, Reimchen TE. 2012. Population genomics of parallel phenotypic evolution in stickleback across stream/lake ecological transitions. Proc Roy Soc Lond B: Biol Sci. 279:1277-1286. PMid:21976692. PMCid:PMC3282360. http://dx.doi.org/10.1098/rspb.2011.1552

DeBoer T, Subia M, Kovitvonga K, Ambariyanto, Erdmann M, Barber PH. 2008. Phylogeography and limited genetic connectivity in the endangered giant boring clam, Tridacna crocea, across the Coral Triangle. Conserv Biol. 22:1255-1266. PMid:18637905. http://dx.doi. org/10.1111/j.1523-1739.2008.00983.x

DeBoer TS, Naguit MR, Erdmann MV, Ablan-Lagman MCA, Ambariyanto, Carpenter KE, Toha AHA, Barber PH. 2014a. Concordant phylogenetic patterns inferred from mitochondrial and microsatellite DNA in the giant clam Tridacna crocea. Bull Mar Sci. 90:301-329. http://dx.doi.org/10.5343/bms.2013.1002

DeBoer TS, Naguit MR, Erdmann MV, Ablan-Lagman MCA, Ambariyanto, Carpenter KE, Toha AHA, Barber PH. 2014b. Concordance between phylogeographic and biogeographic boundaries in the Coral Triangle: conservation implications based on comparative analyses of multiple giant clam species. Bull Mar Sci. 90:277-299. http://dx.doi.org/10.5343/ bms.2013.1003

DiBattista JD, Waldrop E, Bowen BW, Schultz JK, Gaither MR, Pyle RL, Rocha LA. 2012b. Twisted sister species of pygmy angelfishes: discordance between taxonomy, coloration, and phylogenetics. Coral Reefs. 31:839-851. http://dx.doi.org/10.1007/s00338-012-0907-y

DiBattista JD, Craig MT, Rocha LA, Feldheim KA, Bowen BW. 2012a. Phylogeography of the Indo-Pacific butterflyfishes, Chaetodon meyeri and Chaetodon ornatissimus: sister species reveal divergent evolutionary histories and discordant results from mtDNA and microsatellites. J Heredity. 103:617-629. PMid:22888133. http://dx.doi.org/10.1093/jhered/ess056

DiBattista JD, Berumen ML, Gaither MR, Rocha LA, Eble JA, Choat JH, Craig MT, Skillings DJ, Bowen BW. 2013. After continents divide: comparative phylogeography of reef fishes from the Red Sea and Indian Ocean. J Biogeogr. 40:1170-1181. http://dx.doi.org/10.1111/ jbi.12068

Doherty PJ, Planes S, Mather P. 1995. Gene flow and larval duration in seven species of fish from the Great Barrier Reef. Ecology. 78:2373-2391. http://dx.doi.org/10.2307/2265814

Drew JA, Barber PH. 2009. Sequential cladogenesis of the reef fish Pomacentrus moluccensis (Pomacentridae) supports the peripheral origin of marine biodiversity in the IndoAustralian archipelago. Mol Phylogen Evol. 53:335-339. PMid:19401237. http://dx.doi. org/10.1016/j.ympev.2009.04.014

Drew JA, Barber PH. 2012. Comparative phylogeography in Fijian coral reef fishes: a multi-taxa approach towards marine reserve design. PLoS ONE. 7:e47710. http://dx.doi.org/10.1371/ journal.pone.0047710 
Drew JA, Kaufmann L, Allen G, Barber PH. 2008. Endemism and regional color and genetic differences in five putatively cosmopolitan reef fishes. Conserv Biol. 22:965-976. PMid:18786099. http://dx.doi.org/10.1111/j.1523-1739.2008.01011.x

Durban A, Hebert PDN, Cristescu MEA. 2008. Comparative phyiogeography of marine cladocerans. Mar Biol. 155:1-10. http://dx.doi.org/10.1007/s00227-008-0996-x

Dyer RJ, Nason JD. 2004. Population graphs: the graph theoretic shape of genetic structure. Mol Ecol. 13:1713-1728. PMid:15189198. http://dx.doi.org/10.1111/j.1365-294X.2004.02177.x

Dyer Rा, Nason JD, Garrick RC. 2010. Landscape modeling of gene flow: improved power using conditional genetic distance derived from the topology of population networks. Mol Ecol. 19:3746-3759. PMid:20723052. http://dx.doi.org/10.1111/j.1365-294X.2010.04748.x

Eble JA, Toonen RJ, Bowen BW. 2009. Endemism and dispersal: comparative phylogeography of three surgeonfish species across the Hawaiian Archipelago. Mar Biol. 156:689-698. http://dx.doi.org/10.1007/s00227-008-1119-4

Eble JA, Toonen RJ, Sorensen LL, Basch L, Papastamatiou Y, Bowen BW. 2011. Escaping paradise: larval export from Hawaii in an Indo-Pacific reef fish, the yellow tang (Zebrasoma flavescens). Mar Ecol Prog Ser. 428:245-258. http://dx.doi.org/10.3354/meps09083

Ekman S. 1953. Zoogeography of the sea. London: Sidgwick and Jackson.

EytanRI,HellbergME.2010.Nuclearandmitochondrialsequencedatarevealand concealdifferent demographic histories and population genetic processes in Caribbean reef fishes. Evolution. 64:3380-3397. PMid:20584072. http://dx.doi.org/10.1111/j.1558-5646.2010.01071.x

Etter PD, Preston L, Bassham S, Cresko WA, Johnson EA. 2011. Local de novo assembly of RAD paired-end contigs using short sequencing reads. PLoS ONE. 6:e18561. PMid:21541009. PMCid:PMC3076424. http://dx.doi.org/10.1371/journal.pone.0018561

Excoffier L, Hofer T, Foll M. 2009. Detecting loci under seiection in a hierarchically structured population. Heredity. 103:285-298. PMid:19623208. http://dx.doi.org/10.1038/hdy.2009.74

Faircloth BC, McCormack JE, Crawford NG, Harvey MG, Brumfield RT, Glenn TC. 2012. Ultraconserved elements anchor thousands of genetic markers spanning multiple evolutionary timescales. Sys Biol. 61:717-726. PMid:22232343. http://dx.doi.org/10.1093/ sysbio/sys004

Faucci A, Toonen RJ, Hadfield MG. 2007. Host shift and speciation in a coral-feeding nudibranch. Proc Roy Soc Lond B: Biol Sci. 274:111-119. PMid:17134995. PMCid:PMC1679885. http://dx.doi.org/10.1098/rspb.2006.3685

Faurby S, Barber PH. 2012. Theoretical limits to the correlation between pelagic larval duration and population genetic structure. Mol Ecol. 21:3419-3432. PMid:22574811. http://dx.doi. org/10.1111/j.1365-294X.2012.05609.X

Faucci A, Toonen RJ, Hadfield MG. 2007. Host shift and speciation in a coral-feeding nudibranch. Proc Roy Soc Lond B: Biol Sci. 274:111-119. PMid:17134995. PMCid:PMC1679885. http://dx.doi.org/10.1098/rspb.2006.3685

Fauveiot C, Bernardi G, Planes S. 2003. Reductions in the mitochondrial DNA diversity of coral reef fish provide evidence of population bottlenecks resulting from Holocene sealevel change. Evolution. 57:1571-1583. PMid:12940362.

Feder JL, Velez S. 2009. Intergenic exchange, geographic isolation, and the evolution of bioluminescent color for pyrophorus click beetles. Evolution. 63:1203-1216. PMid:19154393. http://dx.doi.org/10.1111/j.1558-5646.2009.00623.x

Fernandez-Silva I, Toonen RJ, Whitney J, Wainwright B, Ylitalo-Ward H, Andrews KR, Goetze E, Bowen BW, Karl SA. 2013. Microsatellites for the next-generation of ecologists: a postsequencing bioinformatics pipeline reduces laboratory testing in microsatellites development from 454. PLoS ONE. 8:e55990. http://dx.doi.org/10.1371/journal.pone.0055990

Floeter SR, Rocha LA, Robertson DR, Joyeux JC, Smith-Vaniz W, Barreiros JP, Wirtz P, Edwards AJ, Ferreira CEL, Gasparini JL, et al. 2008. Atlantic reef fish biogeography and evolution. J Biogeogr. 35:22-47.

Forsman ZH, Concepcion GT, Haverkort RD, Shaw RW, Maragos JE, Toonen RJ. 2010. Ecomorph or endangered coral? DNA and microstructure reveal Hawaiian species 
complexes: Montipora dilatata/flabellata/turgescens \& M. patula/verrilli. PLoS ONE. 5:e15021. PMid:21151995. PMCid:PMC2996308. http://dx.doi.org/10.1371/journal. pone.0015021

Fukuyama F. 1992. The end of history and the last man. New York: Free Press Imprint of Simon \& Schuster. ISBN 0-02-910975-2.

Gaggiotti OE, Bekkevold D, Jørgensen HBH, Foll M, Carvalho GR, Andre C, Ruzzante DE. 2009. Disentangling the effects of evolutionary, demographic and environmental factors influencing genetic structure of natural populations: Atlantic herring as a case study. Evolution. 63:2939-2951. PMid:19624724. http://dx.doi.org/10.1111/j.1558-5646.2009.00779.X

Gagnaire P-A, Minegishi Y, Zenboudji S, Valade P, Aoyama J, Berrebi P. 2011. Withinpopulation structure highlighted by differential introgression across semipermeable barriers to gene flow in Anguilla marmorata. Evolution. 65: 3413-3427. PMid:22133215. http:// dx.doi.org/10.1111/j.1558-5646.2011.01404.x

Gaither MR, Rocha LA. 2013. Origins of species richness in the Indo-Malay-Philippine biodiversity hotspot: evidence for the centre of overlap hypothesis. J Biogeogr. 40:1638-1648. http://dx.doi.org/10.1111/jbi.12126

Gaither MR, Toonen R), Robertson DR, Planes S, Bowen BW. 2010. Genetic evaluation of marine biogeographic barriers: perspectives from two widespread Indo-Pacific snappers (Lutjanus spp.). J Biogeogr. 37:133-147. http://dx.doi.org/10.1111/j.1365-2699.2009.02188.x

Gaither MR, Toonen RJ, Bowen BW. 2012. Coming out of the starting blocks: the importance of lag period and stochasticity in shaping patterns of genetic diversity in marine invaders. Proc Roy Soc Lond B: Biol Sci. 279:3948-3957. PMid:22874747. PMCid:PMC3427594. http://dx.doi.org/10.1098/rspb.2012.1481

Galtier N, Nabholz B, Glemin S. 2009. Mitochondrial DNA as a marker of molecular diversity: a reappraisal. Mol Ecol. 18:4541-4550. PMid:19821901. http://dx.doi. org/10.1111/j.1365-294X.2009.04380.x

Gittenberger A, Gittenberger E. 2011. Cryptic, adaptive radiation of endoparasitic snails: sibling species of Leptoconchus (Gastropoda: Coralliophilidae) in corals. Organ Divers Evol. 11:21-41. http://dx.doi.org/10.1007/s13127-011-0039-1

Goldstien SJ, Schiel DR, Gemmell NJ. 2006. Comparative phylogeography of coastal limpets across a marine disjunction in New Zealand. Mol Ecol. 15:3259-3268. PMid:16968269. http://dx.doi.org/10.1111/j.1365-294X.2006.02977.x

Gotelli N), Anderson M], Arita HT, Chao A, Colwell RK, Connolly SR, Curie DJ, Dunn RR, Graves GR, Green JL, et al. 2009. Patterns and causes of species richness: a general simulation model for macroecology. Ecol Lett. 12:873-886. PMid:19702748. http://dx.doi. org/10.1111/j.1461-0248.2009.01353.x

Hardy SM, Carr CM, Hardman M, Steinke D, Corstorphone E, Mah C. 2011. Biodiversity and phylogeography of Arctic marine fauna: insights from molecular tools. Mar Biodiv. 41:195210. http://dx.doi.org/10.1007/s12526-010-0056-x

Hart MW, Abt CH), Emlet RB. 2011. Molecular phylogeny of echinometrid sea urchins: more species of Heliocidaris with derived modes of reproduction. Invert Biol. 130:175-185. http://dx.doi.org/10.1111/j.1744-7410.2011.00231.x

HebertPDN, Cywinska A, BallSL, deWaard)R.2003. Biological identifications through DNA barcodes. Proc Roy Soc Lond B: Biol Sci. 270:313-321. PMid:12614582. PMCid:PMC1691236. http://dx.doi.org/10.1098/rspb.2002.2218

Helliberg ME. 2009. Gene flow and isolation among populations of marine animals. Ann Rev Ecol Evol Sys. 40: 291-310. http://dx.doi.org/10.1146/annurev.ecolsys.110308.120223

Hellberg ME, Moy GW, Vacquier VD. 2000. Positive selection and propeptide repeats promote rapid interspecific divergence of a gastropod sperm protein. Mol Biol Evol. 17:458-466. PMid:10723746. http://dx.doi.org/10.1093/oxfordjournals.moநbev.a026325

Hickerson MJ, Meyer CP. 2008. Testing comparative phylogeographic models of marine vicariance and dispersal using a hierarchical Bayesian approach. BMC Evol Biol. 8:322. http:// dx.doi.org/10.1186/1471-2148-8-322 
Hickerson MJ, Carstens BC, Cavender-Bares J, Crandall KA, Graham CH, Johnson JB, Rissler L, Victoriano PF, Yoder AD. 2010. Phylogeography's past, present, and future: 10 years after. Mol Phylogen Evol. 54:291-301. PMid:19755165. http://dx.doi.org/10.1016/j. ympev.2009.09.016

Hickey AJR, Lavery SD, Hannan DA, Baker CS, Clements KD. 2009. New Zealand triplefin fishes (family Tripterygiidae): contrasting population structure and mtDNA diversity within a marine species flock. Mol Ecol. 18:680-696. PMid:19215584. http://dx.doi. org/10.1111/j.1365-294X.2008.04052.X

Hobbs J-PA, Frisch AJ, Allen GR, Van Herwerden L. 2009. Marine hybrid hotspot at IndoPacific biogeographic border. Biol Lett. 5:258-261. PMid:19126528. PMCid:PMC2665801. http://dx.doi.org/10.1098/rsbl.2008.0561

Hohenlohe PA, Bassham S, Etter PD, Stiffler N, Johnson EA, Cresko WA. 2011. Population genomics of parallel adaptation in threespine stickleback using sequenced RAD tags. PLoS Genet. 6:e1000862. PMid:20195501. PMCid:PMC2829049. http://dx.doi.org/10.1371/journal.pgen.1000862

Holland BS, Dawson MN, Crow GL, Hofmann DK. 2004. Global phylogeography of Cassiopea (Scyphozoa: Rhizostomeae): molecular evidence for cryptic species and multiple invasions of the Hawaiian Islands. Mar Biol. 145:1119-1128. http://dx.doi.org/10.1007/ s00227-004-1409-4

Horne JB, van Herwerden L, Choat JH, Robertson DR. 2008. High population connectivity across the Indo-Pacific: congruent lack of phylogeographic structure in three reef fish congeners. Mol Phylogen Evol. 49:629-638. PMid:18804542. http://dx.doi.org/10.1016/j. ympev.2008.08.023

Hubby JL, Lewontin RC. 1966. A molecular approach to the study of genic heterozygosity in natural populations. I. The number of alleles at different loci in Drosophila pseudoobscura. Genetics. 54:546-595.

Jokiel P, Martinelli FJ. 1992. The vortex model of coral reef biogeography. J Biogeogr. 19:449458. http://dx.doi.org/10.2307/28455/2

Jordan DS. 1908. The law of the geminate species. Am Nat. 42:73-80. http://dx.doi. org $/ 10.1086 / 278905$

Karl SA, Avise JC. 1993. PCR-based assays of Mendelian polymorphisms from anonymous single-copy nuclear DNA: techniques and applications for population genetics. Mol Biol Evol. 10:342-361. PMid:8098128.

Karl SA, Bowen BW, Avise JC. 1992. Global population structure and male-mediated gene flow in the green turtle (Chelonia mydas): RFLP analysis of anonymous nuclear DNA regions. Genetics. 131:163-173. PMid:1350555. PMCid:PMC1204950.

Kar SA, Toonen RJ, Grant WS, Bowen BW. 2012. Common misconceptions in molecular ecology: echos of the modern synthesis. Mol Ecol. 21:4171-4189. PMid:22574714. http:// dx.doi.org/10.1111/j.1365-294X.2012.05576.X

Kelly RP, Palumbi SR. 2010. Genetic structure among 50 species of the northeastern Pacific rocky intertidal community. PLoS ONE. 5:e8594. http://dx.doi.org/10.1371/journal. pone.0008594

Keyse J, Crandall ED, Toonen RJ, Meyer C, Treml E, Riginos C. 2014. The scope of published population genetic data for Indo-Pacific marine fauna and future research opportunities. Bull Mar Sci. 90:47-78. http://dx.doi.org/10.5343/bms.2012.1107

Kininmonth S, De'ath G, Possingham HP. 2010a. Graph theoretic topology of the Great but small Barrier Reef world. Theoret Ecol. 3:75-88. http://dx.doi.org/10.1007/s12080-009-0055-3

Kininmonth S, van Oppen MJH, Possingham HP. 2010b. Determıning the community structure of the coral Seriatopora hystrix from hydrodynamic and genetic networks. Ecol Model. 221:2870-2880. http://dx.doi.org/10.1016/j.ecolmodel.2010.08.042

Kirkendale LA, CP Meyer. 2004. Phylogeography of the Patelloida profunda group (Gastropoda: Lottidae): diversification in a dispersal-driven marine system. Mol Ecol. 13:2749-2762. PMid:15315686. http://dx.doi.org/10.1111/j.1365-294X.2004.02284.X 
Klanten OS, Choat JH, van Herwerden L. 2007. Extreme genetic diversity and temporal rather than spatial partitioning in a widely distributed coral reef fish. Mar Biol. 150:659-670. http://dx.doi.org/10.1007/s00227-006-0372-7

Kochzius M, Seidei C, Hauschild J, Kirchioff S, Mester P, Meyer-Wachsmuth I, Nuryanto A, Timm J. 2009. Genetic population structure of the blue starfish Linckia laevigata and its gastropod ectoparasite Thyca crystallina. Mar Ecol Prog Ser. 396:211-219. http://dx.doi. org/10.3354/meps08281

Landry C, Geyer LB, Arakaki Y, Uehara T, Palumbi SR. 2003. Recent speciation in the IndoWest Pacific: rapid evolution of gamete recognition and sperm morphology in cryptic species of sea urchin. Proc Roy Soc Lond B: Biol Sci. 270:1839-1847. PMid:12964987. PMCid:PMC1691439. http://dx.doi.org/10.1098/rspb.2003.2395

Landuyt D, Broekx S, D'Hondt R, Engelen G, Aertsens J, Goethals PLM. 2013. A review of Bayesian belief networks in ecosystem services modeling. Environ Model Softw. 46:1-11. http://dx.doi.org/10.1016/j.envsoft.2013.03.011

Lemmon AR, Lemmon EM. 2012. High-throughput identification of informative nuclear loci for shallow-scale phylogenetics and phylogeography. Sys Biol. 61:745-761. PMid:22610088. http://dx.doi.org/10.1093/sysbio/sys051

Leray M, Yang JY, Meyer CP, Mills SC, Agudelo N, Ranwez V, Boehm JT, Machida RJ. 2013. A new versatile primer set targeting a short fragment of the mitochondrial COI region for metabarcoding metazoan diversity: application for characterizing coral reef fish gut contents. Frontiers Zool. 10:34. http://dx.doi.org/10.1186/1742-9994-10-34

Lessios HA. 2008. The great American schism: divergence of marine organisms after the rise of the Central American isthmus. Ann Rev Ecol Evol Syst. 39:63-91. http://dx.doi. org/10.1146/annurev.ecolsys.38.091206.095815

Lessios HA. 2011. Speciation genes in free-spawning marine invertebrates. Integr Compar Biol. 51:456-465. PMid:21700571. http://dx.doi.org/10.1093/icb/icr039

Lessios HA, Kessing BD, Pearse JS. 2001. Population structure and speciation in tropical seas: global phylogeography of the sea urchin Diadema. Evolution. 55:955-975. http://dx.doi. org/10.1554/0014-3820(2001)055[0955:PSASIT]2.0.CO;2

Lewontin RC. 1991. Twenty five years ago in GENETICS: electrophoresis in the development of evolutionary genetics: milestone or millstone? Genetics. 128:657-662. PMid:1916239. PMCid:PMC1204540.

Lourie SA, Green DM, Vincent AC. 2005. Dispersal, habitat differences, and comparative phylogeography of Southeast Asian seahorses (Sygnathidae: Hippocampus). Mol Ecol. 14:1073-1094. PMid:15773937. http://dx.doi.org/10.1111/j.1365-294X.2005.02464.X

Losos JB. 2010 Adaptive radiation, ecological opportunity, and evolutionary determinism. Am Nat. 175:623-639. PMid:20412015. http://dx.doi.org/10.1086/652433

Ludt WB, Bernal M, Bowen BW, Rocha LA. 2012. Living in the past: phylogeography and population histories of Indo-Pacific wrasses (genus Halichoeres) in shallow lagoons versus outer reef slopes. PLoS ONE. 7:e38042. http://dx.doi.org/10.1371/journal.pone.0038042

Maggs CA, Castilho R, Foltz D, Henzler C, olly MT, Kelly ), Olsen J, Perez KE, Stam W, Väinölä R, et al. 2008. Evaluating signatures of glacial refugian for North Atlantic benthic marine taxa. Ecology. 89:S108-S122. PMid:19097488. http://dx.doi.org/10.1890/08-0257.1

Malay MCD, Paulay G. 2009. Peripatric speciation drives diversification and distribution patterns of reef hermit crabs (Decapoda: Diogenidae: Calcinus). Evolution. 64:634-662. PMid:19796150. http://dx.doi.org/10.1111/j.1558-5646.2009.00848.x

Marko PB, Hart MW. 2011. The complex analytical landscape of gene flow inference. Trends Ecol Evol. 26:448-456. PMid:21722987. http://dx.doi.org/10.1016/j.tree.2011.05.007

Marko P, Moran A. 2002. Correlated evolutionary divergence of egg size and a mitochondrial protein across the Isthmus of Panama. Evolution. 56:1303-1309. PMid:12144030.

Maxam AM, Gilbert W. 1977. A new method for sequencing DNA. Proc Natl Acad Sci USA. 74:560-564. http://dx.doi.org/10.1073/pnas.74.2.560 
Mayr E. 1954. Geographic speciation in tropical echinoids. Evolution. 8:1-18. http://dx.doi. org/10.2307/2405661

Meyer CP, Paulay G. 2005. DNA Barcoding: error rates based on comprehensive sampling. PLoS Biology. 3:e422. PMid:16336051. PMCid:PMC1287506. http://dx.doi.org/10.1371/ journal.pbio.0030422

Mirams AGK, Treml EA, Shields JL, Liggins L, Riginos C. 2011. Vicariance and dispersal across an intermittent barrier: population genetic structure of marine animals across the Torres Strait land bridge. Coral Reefs. 30:937-949. http://dx.doi.org/10.1007/s00338-011-0767-x

Montanari SR, van Herwerden L, Pratchett MS, Hobbs J-P A, Fugedi A. 2011. Reef fish hybridization: lessons learnt from butterflyfishes (genus Chaetodon). Ecol Evol. 3:310-328. http:// dx.doi.org/10.1002/ece3.83

Munday PL, van Herwerden L, Dudgeon CL. 2004. Evidence for sympatric speciation by host shift in the sea. Curr Biol. 14:1498-1504. PMid:15324668. http://dx.doi.org/10.1016/j. cub.2004.08.029

Nosil P, Feder JL. 2012. Genomic divergence during speciation: causes and consequences. Phil Trans Roy Soc B: Biol Sci. 367:332-342. PMid:22201163. PMCid:PMC3233720. http:// dx.doi.org/10.1098/rstb.2011.0263

Nielsen EE, Hemmer-Hansen J, Poulsen NA, Loeschcke V, Moen T, Johansen T, Mittelholzer C, Taranger G-L, Ogden R, Carvalho GR. 2009. Genomic signatures of local directional selection in a high gene flow marine organism; the Atlantic cod (Gadus morhua). BMC Evol Biol. 9:276. PMid:19948077. PMCid:PMC2790465. http://dx.doi.org/10.1186/1471-2148-9-276

O'Loughlin PM, Paulay G, Davey N, Michonneau F. 2011. The Antarctic region as a marine biodiversity hotspot for echinoderms: diversity and diversification of sea cucumbers. Deep Sea Res II. 58:264-275. http://dx.doi.org/10.1016/j.dsr2.2010.10.011

Palumbi SR 1997. Molecular biogeography of the Pacific. Coral Reefs. 16:S47-S52. http:// dx.doi.org/10.1007/s003380050241

Palumbi SR, Lessios HA. 2005. Evolutionary animation: how do molecular phylogenies compare to Mayr's reconstruction of speciation patterns in the sea? Proc Natl Acad Sci USA. 102:6566-6572. PMid:15851681. PMCid:PMC1131860. http://dx.doi.org/10.1073/ pnas.0501806102

Paulay G. 1997. Diversity and distribution of reef organisms. In: Birkeland CE, editor. Life and death of coral reefs. New York: Chapman \& Hall. p. 298-353. http://dx.doi. org/10.1007/978-1-4615-5995-5_14

Paulay G, Meyer C. 2006. Dispersal and divergence across the greatest ocean region: do larvae matter? Integr Comp Biol. 46:269-281. PMid:21672741. http://dx.doi.org/10.1093/icb/ icj027

Paulay G, Starmer J. 2011. Evolution, insular restriction, and extinction of oceanic land crabs, exemplified by the loss of an endemic Geograpsus in Hawai'i. PLoS ONE. 6:e19916. PMid:21603620. PMCid:PMC3095624. http://dx.doi.org/10.1371/journal.pone.0019916

Pelc RA, Warner RR, Gaines SD. 2009. Geographic patterns of genetic structure in marine species with contrasting life histories. J Biogeogr. 36:1881-1890. http://dx.doi. org/10.1111/j.1365-2699.2009.02138.x

Pespeni MH, Garfield DA, Manier MK, Palumbi SR. 2012. Genome-wide polymorphisms show unexpected targets of natural selection. Proc Roy Soc Lond B: Biol Sci. 279:1412-1420. PMid:21993504. PMCid:PMC3282374. http://dx.doi.org/10.1098/rspb.2011.1823

Planes S, Fauvelot C. 2002. Isolation by distance and vicariance drive genetic structure of a coral reef fish in the Pacific Ocean. Evolution. 56:378-399. PMid:11926506.

Planes S, Parroni M, Chauvet C. 1998. Evidence oflimited gene flow in three species of coral reef fishes in the lagoon of New Caledonia. Mar Biol. 130:361-368. http://dx.doi.org/10.1007/ s002270050256

Plouviez S, Shank TM, Faure B, Daguin-Thiebaut C, Viard F, Lallier FH, Jollivet D. 2009. Comparative phylogeography among hydrothermal vent species along the East Pacific Rise 
reveals vicariant processes and population expansion in the south. Mol Ecol. 18:3903-3917. PMid:19709370. http://dx.doi.org/10.1111/j.1365-294X.2009.04325.X

Puebla O, Bermingham E, Guichard F, Whiteman E. 200\%. Colour pattern as a single trait driving speciation in Hypoplectrus coral reef fishes? Proc Roy Soc B: Biol Sci. 274:1265-1271. PMid:17360287. PMCid:PMC2176177. http://dx.doi.org/10.1098/rspb.2006.0435

Puritz JB, Addison JA, Toonen RJ. 2012a. Next-generation phylogeography: a targeted approach for multilocus sequencing of non-model organisms. PloS ONE. 7:e34241. PMid:22470543. PMCid:PMC3314618. http://dx.doi.org/10.1371/journal.pone.0034241

Puritz JB, Keever CC, Adđison JA, Byrne M, Hart MW, Grosberg RK, Toonen RJ. 2012b. Extraordinarily rapid life-history divergence between Cryptasterina sea star species. Proc Roy Soc Lond B: Biol Sci. 279:3914-3922. PMid:22810427. PMCid:PMC3427584. http:// dx.doi.org/10.1098/rspb.2012.1343

Quinn TW, White BN. 1987. Identification of restriction-fragment-length polymorphisms in genomic DNA of the lesser snow goose (Anser caerulescens caerulescens). Mol Biol Evol. 4:126-143. PMid:2895887.

Radwan J, Babik W. 2012. The genomics of adaptation. Proc Roy Soc Lond B: Biol Sci. 279:50245028. PMid:23097510. http://dx.doi.org/10.1098/rspb.2012.2322

Rahbek C, Gotelli NJ, Colwell RK, Entsminger GL, Rangel TFL, Graves GR. 2007. Predicting continental-scale patterns of bird species richness with spatially explicit models. Proc Roy Soc Lond B: Biol Sci. 274:165-174. PMid:17148246. PMCid:PMC1685854. http://dx.doi. org/10.1098/rspb.2006.3700

Randall JE. 2001. Four new cardinalfishes (Perciformes: Apogonidae) from the Marquesas Islands. Pac Sci. 55:47-64. http://dx.doi.org/10.1353/psc.2001.0006

Reece JS, Bowen BW, Larson A. 2011. Long larvai duration in moray eels (Muraenidae) ensures ocean-wide connectivity despite differences in adult niche breadth. Mar Ecol Prog Ser. 437:269-277. http://dx.doi.org/10.3354/meps09248

Reid DG, Lal K, Mackenzie-Dodds ,, Kaligis F, LittlewoodDTJ, Williams ST. 2006. Comparative phylogeography and species boundaries in Echinolittorina snails in the central Indo-West Pacific. J Biogeogr. 33:990-1006. http://dx.doi.org/10.1111/j.1365-2699.2006.01469.x

Riginos C, Victor BC. 2001. Larval spatial distributions and other early life-history characteristics predict genetic differentiation in eastern Pacific blennioid fishes. Proc Roy Soc Lond B: Biol Sci. 268:1931-1936. http://dx.doi.org/10.1098/rspb.2001.1748

Riginos C, Liggins L. 2013. Seascape genetics: populations, individuals, and genes marooned and adrift. Geography Compass. http://dx.doi.org/10.1111/gec3.12032

Riginos C, Douglas KE, Jin Y, Shanahan DF, TremI EA. 2011. Effects of geography and life history traits on genetic differentiation in benthic marine fishes. Ecography. 34:566-575. http://dx.doi.org/10.1111/j.1600-0587.2010.06511.x

Roberts CM, McClean CJ, Veron JEN, Hawkins JP, Allen GR, McAllister DE, Mittermeier CG, Schueler FW, Spalding M, Wells F, et al. 2002. Marine biodiversity hotspots and conservation priorities for tropical reefs. Science. 295:1280-1284. PMid:11847338. http://dx.doi. org/10.1126/science.1067728

Rocha LA. 2004. Mitochondrial DNA and color pattern variation in three western Atlantic Halichoeres (Labridae), with the revalidation of two species. Copeia. 2004:770-782. http:// dx.doi.org/10.1643/CG-04-106

Rocha LA, Bowen BW. 2008. Speciation in coral-reef fishes. J Fish Biol. 72:1101-1121. http:// dx.doi.org/10.1111/j.1095-8649.2007.01770.x

Rocha LA, Bass AL, Robertson DR, Bowen BW. 2002. Adult habitat preferences, larval dispersal, and the comparative phylogeography of three Atlantic surgeonfishes (Teleostei: Acanthuridae). Mol Ecol. 11:243-252. PMid:11856425. http://dx.doi. org/10.1046/j.0962-1083.2001.01431.X

Rocha LA, Robertson DR, Roman J, Bowen BW. 2005. Ecological speciation in tropical reef fishes. Proc Roy Soc Lond B: Biol Sci. 272:573-579. 
Rocha LA, Craig MT, Bowen BW. 2007. Phylogeography and the conservation of coral reef fishes. Coral Reefs. 26:501-512. http://dx.doi.org/10.1007/s00338-007-0261-7

Rocha LA, Bernal MA, Gaither MR, Alfaro ME. 2013. Massively parallel DNA sequencing: the new frontier in biogeography. Front Biogeogr. 5:67-77 .

Rocha-Olivares A, Fleeger JW, Foltz DW. 2001. Decoupling of molecular and morphological evolution in deep lineages of a meiobenthic harpacticoid copepod. Mol Biol Evol. 18:10881102. PMid:11371597. http://dx.doi.org/10.1093/oxfordjournals.molbev.a003880

Roesti M, Salzburger W, Berner D. 2012. Unınformative polymorphisms bias genome scans for signatures of selection. BMC Evol Biol. 12:94. http://dx.doi.org/10.1186/1471-2148-12-94

Rosenblatt RH, Waples RS. 1986. A genetic comparison of allopatric populations of shore fish species from the eastern and central Pacific Ocean: dispersal or vicariance? Copeia. 1986:275-284. http://dx.doi.org/10.2307/1444988

Sa-Pinto A, Branco M, Sayanda D, Alexandrino P. 2008. Patterns of colonization, evolution, and gene flow in species of the genus Patella in the Macaronesian Islands. Mol Ecol. 17:519532. PMid:18179442. http://dx.doi.org/10.1111/j.1365-294X.2007.03563.x

Sanford E, Kelly MW. 2011. Local adaptation in marine invertebrates. Ann Rev Mar Sci. 3:509535. http://dx.doi.org/10.1146/annurev-marine-120709-142756

Sanger F, Coulson AR. 1975. A rapid method for determining sequences in DNA by primed synthesis with DNA polymerase. J Mol Biol. 94:441-448. http://dx.doi. org/10.1016/0022-2836(75)90213-2

Sbrocco EJ, Barber PH. 2013. MARSPEC: ocean climate layers for marine spatial ecology. Ecology. 94:979-979. http://dx.doi.org/10.1890/12-1358.1

Schulze SR, Rice SA, Simon JL, Karl SA. 2000. Evolution of poecilogony and the biogeography of North American populations of the polychaete Streblospio. Evolution. 54:1247-1259. PMid:11005292.

Seehausen O, Terai Y, Magalhaes IS, Carleton KL, Mrosso HDJ, Miyagi R, van der Sluijs I, Schneider MV, Maan ME, Tachida H, et al. 2008. Speciation through sensory drive in cichlid fish. Nature. 455:620-626. PMid:18833272. http://dx.doi.org/10.1038/nature07285

Selkoe KA, Henzler CM, Gaines SD. 2008. Seascape genetics and the spatial ecology of marine populations. Fish Fish. 9:363-377. http://dx.doi.org/10.1111/j.1467-2979.2008.00300.x

Selkoe KA, Watson JR, White C, Horin TB, lacchei M, Mitarai S, Siegel DA, Gaines SD, Toonen RJ. 2010. Taking the chaos out of genetic patchiness: seascape genetics reveals ecological and oceanographic drivers of genetic patterns in three temperate reef species. Mol Ecol. 19:3708-3726. PMid:20723063. http://dx.doi.org/10.1111/j.1365-294X.2010.04658.x

Selkoe KA, Toonen RJ. 2011. Marine connectivity: a new look at pelagic larval durations and genetic metrics of dispersal. Mar Ecol Prog Ser. 436:291-305. http://dx.doi.org/10.3354/ meps09238

Shulman MJ, Bermingham E. 1995. Early life histories, ocean currents, and the population genetics of Caribbean reef fishes. Evolution. 49:897-910. http://dx.doi.org/10.2307/2410412

Sotka EE. 2005. Local adaptation in host use among marine invertebrates. Ecol Lett. 8:448-459. http://dx.doi.org/10.1111/j.1461-0248.2004.00719.x

Stat M, Baker AC, Bourne DG, Correa AM, Forsman Z, Huggett MJ, Pochon X, Skillings D, Toonen RJ, van Oppen MJH, et al. 2012. Molecular delineation of species in the coral holobiont. Advances Mar Biol. 63:1-66. PMid:22877610. http://dx.doi.org/10.1016/ B978-0-12-394282-1.00001-6

Stepien CA, Rosenblatt RH. 1991. Patterns of gene flow and genetic divergence in the northeastern Pacific Clinidae (Teleostei: Blennioidei), based on allozyme and morphological data. Copeia. 1991:873-896. http://dx.doi.org/10.2307/1446084

Szabó Z, Snelgrove B, Craig MT, Rocha LA, Bowen BW. 2014. Phylogeography of the manybar goatfish, Parupeneus multifasciatus, reveals moderate structure between the central and North Pacific and a cryptic endemic species in the Marquesas Islands. Bull Mar Sci. 90:493-512. http://dx.doi.org/10.5343/bms.2013.1032 
Taylor MS, Hellberg ME. 2006. Comparative phylogeography in a genus of coral reef fishes: biogeographic and genetic concordance in the Caribbean. Mol Ecol. 15:695-707. PMid:16499695. http://dx.doi.org/10.1111/j.1365-294X.2006.02820.x

Timm J, Figiel M, Kochzius M. 2008. Contrasting patterns in species boundaries and evolution of anemonefishes (Amphiprioninae, Pomacentridae) in the centre of marine biodiversity. Mol Phyl Evol. 49:268-276. PMid:18513996. http://dx.doi.org/10.1016/j.ympev.2008.04.024

Timm J, Planes S, Kochzius M. 2012. High similarity of genetic population structure in the false clown anemonefish (Amphiprion ocellaris) found in microsatellite and mitochondrial control region analysis. Cons Gen. 13:693-706. http://dx.doi.org/10.1007/s10592-012-0318-1

Toews DP, Brelsford A. 2012. The biogeography of mitochondrial and nuclear discordance in animals. Mol Ecol. 21:3907-3930. PMid:22738314. http://dx.doi. org/10.1111/j.1365-294X.2012.05664.X

Toonen RJ, Andrews KR, Baums IB, Bird CE, Concepcion CT, Daly-Engel TS, Eble JA, Faucci A, Gaither MR, Iacchei M, et al. 2011. Defining boundaries for applying ecosystem-based management: a multispecies case study of marine connectivity across the Hawaiian Archipelago. J Mar Biol. 2011:460173. http://dx.doi.org/10.1155/2011/460173

Van de Putte AP, Janko K, Kasparova E, Maes GE, Rock ), Koubbi P, Volckaert FAM, Choleva L, Fraser KPP, Smysla J, et al. 2011. Comparative phylogeography of three trematomid fishes reveals contrasting genetic structure patterns in benthic and pelagic species. Mar Genomics. 8:22-34.

Vogler C, Benzie J, Lessios H, Barber PH, Worheide G. 2008. A threat to coral reefs multiplied? Four species of crown of thorns starfish. Biol Lett. 4:696-699. PMid:18832058. PMCid:PMC2614177. http://dx.doi.org/10.1098/rsbl.2008.0454

Von der Heyden S. 2009. Why do we need to integrate population genetics into South African marine protected area planning? African J Mar Sci. 31:263-269. http://dx.doi.org/10.2989/ AJMS.2009.31.2.14.886

Waples RS, Rosenblatt RH. 1987. Patterns of larval drift in southern California marine shore fishes inferred from allozyme data. Fish Bull. 85:1-11.

Wares JP. 2002. Community genetics in the Northwestern Atlantic intertidal. Mol Ecol. 11:1131-1144. PMid:12074721. http://dx.doi.org/10.1046/j.1365-294X.2002.01510.x

Wares JP, Cunningham CW. 2001. Phylogeography and the historical ecology of the North American intertidal. Evolution. 55:2455-2469. PMid:11831661.

Wares J, Pringle J. 2008. Drift by drift: effective population size is limited by advection. BMC Evol Biol. 8:235. PMid:18710549. PMCid:PMC2536672. http://dx.doi. org/10.1186/1471-2148-8-235

Wares JP, Gaines SD, Cunningham CW. 2001. A comparative study of asymmetric migration events across a marine biogeographic boundary. Evolution. 55:295-306. PMid:11308087.

Wares JP, Barber PH, Ross-Ibarra J, Sotka E, Toonen Rा. 2006. Mitochondrial DNA and population size. Science. 314:1388-1389. http://dx.doi.org/10.1126/science.314.5804.1388

Waters JM, Fraser CI, Hewitt GM. 2013. Founder take all: density-dependent processes structure biodiversity. Trends Ecol Evol. http://dx.doi.org/10.1016/j.tree.2012.08.024

Watson JD. 1990. The human genome project: past, present \& future. Science. 248:44-49. PMid:2181665. http://dx.doi.org/10.1126/science.2181665

Wiens JJ, Graham CH. 2005. Niche conservatism: integrating evolution, ecology, and conservation biology. Ann Rev Ecol Evol System. 36:519-539. http://dx.doi.org/10.1146/annurev. ecolsys.36.102803.095431

Willette DA, Allendorf FW, Barber PH, Barshis DJ, Carpenter KE, Crandall ED, Cresko WA, Fernandez-Silva I, Matz MV, Meyer E, et al. 2014. So, you want to use next-generation sequencing in marine systems? Insight from the Pacific Advanced Studies Institute. Bull Mar Sci. 90:79-122. http://dx.doi.org/10.5343/bms.2013.1008

Williams ST, Benzie JAH. 1997. Indo-West Pacific patterns of genetic differentiation in the high-dispersal starfish Linckia laevigata. Mol Ecol 6:559-573. http://dx.doi. org/10.1046/j.1365-294X.1997.00221.x 
Williams ST, Benzie JAH. 1998. Evidence of a biogeographic break between populations of a high dispersal starfish: congruent regions within the Indo-west Pacific defined by color morphs, mtDNA, and allozyme data. Evolution. 52:87-99. http://dx.doi.org/10.2307/2410923

Williams ST, Knowlton N. 2001. Mitochondrial pseudogenes are pervasive and often insidious in the snapping shrimp Genus Alpheus. Mol Biol Evol. 18:1484-1493. PMid:11470839. http://dx.doi.org/10.1093/oxfordjournals.molbev.a003934

Williams S, Apte D, Ozawa T, Kaligis F, Nakano T. 2011. Speciation and dispersal along continental coastlines and island arcs in the Indo-west Pacific turbinid gastropod genus Lunella. Evolution. 65:1752-1771. PMid:21644961. http://dx.doi. org/10.1111/j.1558-5646.2011.01255.x

Williamson S, Hernandez R, Fledel-Alon A, Zhu L, Nielsen R, Bustamante CD. 2005. Simultaneous inference of selection and population growth from patterns of variation in the human genome. Proc Natl Acad Sci USA. 102:7882-7887. PMid:15905331. PMCid:PMC1142382. http://dx.doi.org/10.1073/pnas.0502300102

Yasuda N, Nagai S, Hamaguchi M, Gerard K, Nadaoka K. 2009. Gene flow of Acanthaster plan$c i$ (L.) in relation to ocean currents revealed by microsatellite analysis. Mol Ecol. 18:15741590. PMid:19302361. http://dx.doi.org/10.1111/j.1365-294X.2009.04133.x

Zink RM, Barrowclough GF.2008. MitochondrialDNA under siege in avian phylogeography. Mol Ecol. 17:2107-2121. PMid:18397219. http://dx.dol.org/10.1111/j.1365-294X.2008.03737.x

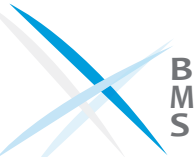

